Illinois State University

ISU ReD: Research and eData

Theses and Dissertations

3-18-2016

\title{
The Role of Official Misconduct in Wrongful Convictions
}

Mia Gilliam

Illinois State University, mrgilli@ilstu.edu

Follow this and additional works at: https://ir.library.illinoisstate.edu/etd

Part of the Criminology Commons, and the Criminology and Criminal Justice Commons

\section{Recommended Citation}

Gilliam, Mia, "The Role of Official Misconduct in Wrongful Convictions" (2016). Theses and Dissertations. 501.

https://ir.library.illinoisstate.edu/etd/501

This Thesis is brought to you for free and open access by ISU ReD: Research and eData. It has been accepted for inclusion in Theses and Dissertations by an authorized administrator of ISU ReD: Research and eData. For more information, please contact ISUReD@ilstu.edu. 
THE ROLE OF OFFICIAL MISCONDUCT

\title{
IN WRONGFUL CONVICTIONS
}

\author{
Mia R. Gilliam
}

\section{Pages}

As the number of wrongful convictions and exonerations of individuals imprisoned for crimes they did not commit has increased dramatically, the study of wrongful conviction has become increasingly important. The majority of past research has focused on the various causes of wrongful convictions. However, very little attention is given in detail to the specific nature of each of these causes. This thesis examined the most current, inclusive database of exonerations in the United States, the National Registry of Exonerations. Qualitative and quantitative data were examined and refined, and statistical analyses were run including descriptives, frequencies, and correlations to gain a better understanding of what role official misconduct plays in contributing to wrongful convictions. A content analysis of 814 cases involving official misconduct was conducted to provide deeper insight into the nature of official misconduct including its perpetrators and the actions that constitute misconduct.

KEYWORDS: Misconduct, Police, Prosecutorial, Wrongful Conviction 
THE ROLE OF OFFICIAL MISCONDUCT

IN WRONGFUL CONVICTIONS

MIA R. GILLIAM

A Thesis Submitted in Partial Fulfillment of the Requirements for the Degree of

MASTER OF SCIENCE

Department of Criminal Justice Sciences

ILLINOIS STATE UNIVERSITY

2016 
(C) 2016 Mia R. Gilliam 
THE ROLE OF OFFICIAL MISCONDUCT

IN WRONGFUL CONVICTIONS

MIA R. GILLIAM

COMMITTEE MEMBERS:

Michael C. Gizzi, Chair

Shelly Clevenger

Ralph Weisheit 


\section{ACKNOWLEDGMENTS}

I wish to thank Dr. Michael Gizzi, Chairperson, who has been an excellent advisor throughout my time during this program. Without your excitement for this project, it would never have been possible to finish. To Dr. Ralph Weisheit, for serving on this committee and providing me with encouragement, guidance, and incredibly quick feedback. I would also like to thank Dr. Shelly Clevenger for not only serving on this committee, but also for being such an incredible mentor and friend. You have taught me how to balance having an enjoyable life experience and continuing to maintain a successful academic career. That is a lesson I will never forget.

I would also like to thank my friends, family, and my amazing cohort for your patience and understanding throughout this process. You're all incredible. Especially Kelsie Langheim, who understands just about everything without judgment.

To Mark Hartman. Without your kind words and support throughout my entire life, I would not be as driven as I am. Thank you for teaching me that it is okay to "dial it back" and take a chance on new things and new people. You're an incredible man and I am so thankful you're such a big part of my life. I love you.

To my mom, Alyssa Marcantonio. Your unwavering faith in me was unprecedented. You've taught me the value of education, hard work, and perseverance. My gratitude will never be enough. Thank you for the opportunity you have given me 
pursue any future endeavors without fear of failure in your eyes. I am constantly in awe of you. You're amazing. I love you.

M. R. G. 


\section{CONTENTS}

ACKNOWLEDGMENTS

TABLES

\section{CHAPTER}

I. INTRODUCTION

$\begin{array}{ll}\text { Introduction } & 1\end{array}$

II. LITERATURE REVIEW

$\begin{array}{ll}\text { Literature Review } & 7\end{array}$

History of Wrongful Convictions $\quad 7$

$\begin{array}{ll}\text { Paradigm shift } & 9\end{array}$

Defining Wrongful Conviction in Past Research 11

Prevalence of Wrongful Conviction 13

$\begin{array}{ll}\text { Innocence projects } & 15\end{array}$

Factors Causing Wrongful Conviction 16

$\begin{array}{ll}\text { Official misconduct } & 18\end{array}$

Prosecutorial misconduct 19

Police misconduct 24

Flawed science $\quad 26$

Eyewitness misidentifications $\quad 27$

False confession $\quad 28$

iii 
Research Design

Research Questions

Limitations

Conclusion

Research Question 1: Other Contributing Factors and Official Misconduct

Research Question 2: Official Misconduct Offenders

Police and prosecutorial misconduct

Police and other criminal justice participant

Research Question 3: Nature of Official Misconduct

Police and prosecutors withhold evidence

Other criminal justice participant misconduct co-occurrences

Coerced false confessions and intimidating interrogation 66

Discussion 


\section{TABLES}

Table

Page

1. Quantitative Analysis Variables 38

2. Content Analysis Coding Scheme 40

3. Descriptive Statistics - National Registry of Exonerations 44

4. Co-Occurrences of Contributing Factors 45

5. Chi-Squared Phi Values of the Contributing Factors 46

6. Descriptive Statistics of Official Misconduct Dataset 47

7. Frequencies of Official Misconduct Dataset 49

8. Number of Official Misconduct Offenders 49

9. Co-Occurrences of Official Misconduct Offenders 50

10. Chi-Squared Phi Values of Official Misconduct Offenders 51

11. Frequencies of Official Misconduct Sub-Categories 56

12. Co-Occurrences of Official Misconduct Sub-Categories 58

13. Chi-Squared Phi Values of Official Misconduct Sub-Categories 60 


\section{CHAPTER I \\ INTRODUCTION}

\section{Introduction}

It is plausible that some instances of wrongful convictions are the result of honest mistakes. However, it is common that the individuals responsible for uncovering the truth and ensuring that justice occurs are too focused on procuring convictions and fail to remember their true responsibilities. Official misconduct occurs by law enforcement officials and prosecutors in a wide variety of forms. Since the criminal justice system is a man-made construct it is wrought with the possibility for negligence, misconduct, and corruption (Innocence Project, 2015). As such, it is highly probable that these instances of misconduct are not strictly isolated to certain circumstances. Although the majority of prosecutors and law enforcement officials are honest, wrongful convictions will be an issue even if only a handful of officers and prosecutors are corrupt.

Thirty-one year old Christine Morton was found bludgeoned to death in her bed following a birthday dinner for her husband Michael with their three-year-old son, on August 13, 1986. Michael was arrested and charged with her murder. During the investigation it was discovered that Eric, the Morton's three-year-old son, was present during the murder. When questioned, Eric told investigators that "the murderer was a 'monster' and that his 'Daddy' was 'not home' when it happened” (National Registry of Exonerations, 2016). Neighbors told police that a man in a green van had repeatedly 
been parking behind the Morton's house. Moreover, the man had been seen walking away into a wooded area.

However, Morton's defense lawyers claimed that they were never made aware of any of this evidence at the trial (National Registry of Exonerations). Michael Morton was convicted in 1987 for his wife's murder and given a life sentence. Prosecutors believed he had beaten Christine to death because she refused to have sex with him on his birthday, but offered no witnesses or physical evidence linking Morton to the crime (National Registry of Exonerations, 2016). Morton's defense raised concerns with the judge regarding the prosecution's decision not to call Sgt. Don Wood, the chief investigator in the case, to the stand, as "they suspected that the prosecution might be concealing potentially exculpatory evidence" (National Registry of Exonerations, 2016). In response the prosecution presented a sealed file for the judge's review allegedly containing all of Sgt. Wood's notes and reports. However, evidence concerning Eric's eyewitness account, the green van, and Christine's Visa card being found in San Antonio were not included in the file (National Registry of Exonerations, 2016).

After spending nearly 25 years in prison, Michael Morton was released in October of 2011 and officially exonerated in December of 2011. DNA testing on crime scene evidence cleared Michael and implicated another man. Of greater consequence was the unearthing of proof that the prosecutors purposefully withheld key evidence that might have prevented his conviction. At the urging of the Innocence Project working for Mr. Morton, the Texas Supreme Court convened an unprecedented Court of Inquiry in order to establish whether the former prosecutor, Ken Anderson, who later became a judge, had committed misconduct (National Registry of Exonerations, 2016). Mr. Anderson was 
charged with criminal contempt for concealing evidence and was brought up on ethics charges by the State Bar of Texas (National Registry of Exonerations, 2016). Anderson has since pled guilty to the criminal contempt charge, served four days of a ten-day jail sentence, and has resigned as a district court judge and permanently relinquished his law license (National Registry of Exonerations, 2016). Throughout history the concept of the criminal justice system wrongfully convicting an individual was believed to be incredibly rare. However numerous people have suffered wrongful convictions for decades (Gould \& Leo, 2010). Innocent individuals who are wrongfully convicted may suffer a variety of consequences including having to abandon their children and being placed in prison environments, many of which are quite dangerous (Grounds, 2004). Society also suffers as a result of wrongful convictions, as the true perpetrator remains at large and free to victimize and harm others (Huff, 2002). Wrongful convictions have been addressed in research since 1932 when Edward Borchard discovered that innocent people had been wrongfully convicted in 65 cases. Bedau and Radelet's (1987) study replicated Borchard's (1932) research using capital cases and found that 23 innocent defendants had been wrongfully executed. Since 1932, numerous researchers have continued to analyze wrongful convictions, focusing on the causes and consequences (Gould \& Leo, 2010; Gross, Jacoby, Matheson, Montgomery, \& Patel, 2005; Huff, 2004; Huff, Rattner, \& Sagarin, 1986; Martin, 2002; Ramsey \& Frank, 2007).

As a result of post-conviction DNA testing in 1990, numerous people, previously convicted of serious crimes, have been exonerated (Innocence Project, 2015). In 1989, Gary Dotson became the first innocent person in the United States to be exonerated as a result of post-conviction DNA testing (Garrett \& Neufeld, 2009). In 1979, Dotson was 
convicted of rape and sentenced to $25-50$ years in prison. After being denied a pardon, despite the recanting of the victim's statement, DNA testing was conducted. Based on the DNA results that excluded Dotson from being the source for the male genetic profile, Dotson's conviction was vacated. Since then, according to data conducted by The Innocence Project (2015), a group that works to free the innocent prisoners through DNA testing, 325 cases DNA exonerations have occurred. The public began to believe that some of these claims of innocence were indeed true and began searching for ways to assist those who have been wrongfully convicted (Krieger, 2011). Consequently, academic research and community awareness surrounding wrongful convictions radically increased (Gross et al., 2005).

The criminal justice system can be modeled in a number of ways. The crime control model of the criminal justice system places great value on suppressing crime by efficiently apprehending, trying, and convicting as many offenders as possible (Goldenstein, 1973; Packer, 1968). Crime control emphasizes quick resolution of questions of guilt through the use of informal investigative processes with very minimal amounts of oversight or review (Findley, 2008). It is not surprising then, that one of the most common factors associated with wrongful convictions is official misconduct. Alaister Logan, a British lawyer who studies wrongful conviction cases in the United States, Canada, and Great Britain, claims to have found instances of deliberate suppression of evidence by police or prosecutors in every case he has studied (Clayton, 1995). Regardless of the expected nature of the prosecutor's job, the belief remains that a central aspect of their job is to "win" or garner a conviction (Ferguson-Gilbert, 2001; Schoenfeld, 2005). As a result of the extreme emphasis on garnering convictions, the 
criminal justice system has a tendency to ignore errors that may have been made, and if addressed, they are accepted as simple collateral damage to reach the desired end result of a conviction. This notion is at the heart of argument presented in William Stuntz's (2011) book, The Collapse of American Criminal Justice. Stuntz (2011) points out the specific changes within the system over time, such as abandoning local democratic control, which has greatly contributed to costly outcomes for citizens.

Unfortunately, although researchers and non-profit organizations have done much to expose wrongful convictions, more cases are identified each month by the National Registry of Exonerations, a joint project of Northwestern University and the University of Michigan law schools. The purpose of this thesis is to examine factors underlying exonerations, with a particular focus on the issue of official misconduct. The National Registry of Exonerations is a joint project of the University of Michigan Law School and the Center for Wrongful Conviction at Northwestern University Law School. The Registry records information on every known exoneration since 1989 and has recorded official misconduct as a factor in 812 (approximately 47 percent) of all exoneration cases.

The National Registry Exonerations defines official misconduct as "police, prosecutors, or other government officials significantly abused their authority or the judicial process in a manner that contributed to the exoneree's conviction." However, the registry does not tell us the nature of the official misconduct. Are these cases involving prosecutors? Police? Other criminal justice officials? We know that official misconduct is a major contributor to wrongful conviction but do not know the substance of it. It is the goal of this thesis to uncover that, through a qualitative examination of all wrongful conviction cases that include official misconduct. More specifically it will focus on 
answering the following questions: (1) what other contributing factors to wrongful convictions are associated with official misconduct? (2) What criminal justice officials are engaged in misconduct? And (3) what is the nature of official misconduct? What types of acts constitute misconduct? 


\section{CHAPTER II}

\section{LITERATURE REVIEW}

\section{Literature Review}

Wrongful convictions have come to be regarded as more commonplace than in the past, when they were viewed as extremely atypical occurrences. As a result of postconviction DNA testing in 1990, numerous people, previously convicted of serious crimes, have been exonerated (Innocence Project, 2015). In 1989, Gary Dotson became the first innocent person in the United States to be exonerated as a result of postconviction DNA testing (Garrett \& Neufeld, 2009). In 1979, Dotson was convicted of rape and sentenced to 25-50 years in prison. After being denied a pardon, despite the recanting of the victim's statement, DNA testing was conducted. Based on the DNA results that excluded Dotson from being the source for the male genetic profile, Dotson's conviction was vacated. Between the exoneration of Dotson and January 2016, according to data conducted by The National Registry of Exonerations (2015), a group that works to provide information on past exonerations of innocent criminal defendants, 1,722 exonerations have occurred.

\section{History of Wrongful Convictions}

Much of the study of wrongful convictions developed from the study of wrongful executions. During the $16^{\text {th }}$ and $17^{\text {th }}$ centuries, known as the Age of Enlightenment, 
scholars began investigating cases in which innocent people were tried, convicted, and was focused on science and reason. As a result, people began to question certain aspects of society, such as the spiritual reasoning used to explain crimes and phenomena of the past. Rationality took center stage during this era. Consequently, scholars began to realize there was a possibility that innocent people had been convicted, and in doing so, became wrongful victims. Scholars began their examination with cases in which someone had been executed for murder when the alleged victim appeared years later alive and well (Smith, 2005).

Sir William Blackstone was an English jurist who authored a book describing the doctrines of English law in the $18^{\text {th }}$ century. His interpretation of the law was quite clear, “...it is better that ten guilty persons escape, than one innocent suffer," (Smith, 2005, p. 4). Our constitution attempts to abide by this idea and combat the risk of error in prosecution (Findley, 2008). However, it has been well established that in practice, this intention does not always play out in the way framers of the constitution had imagined. The framers of the Constitution, in concentrating on the rights of the accused in the Bill of Rights, focused on due process, and in doing so, set the stage for a call to action regarding the consideration of alternate explanations throughout the criminal justice process. The criminal justice system was to be focused on due process, not on crime control. Therefore great importance was placed on the amount of time devoted to looking into a case in which a person may lose his or her freedom. Attention to wrongful convictions was inconsistent for the next 250 years. This inconsistency could be attributed to difficulty ascertaining the true prevalence of wrongful convictions over time. However after the first DNA exoneration, wrongful convictions became a topic of 
massive amounts of attention. It was proof that the criminal justice system was not infallible and mistakes could be made.

Much of the lack of attention to wrongful convictions is by design at the hands of those involved in these cases, such as prosecutors and law enforcement. Some of the inattention to the prevalence of wrongful convictions can also be attributed to the rising number of plea bargains. It is a common misconception that any suspect would not be willing to accept a plea bargain unless he or she had actually committed the crime of which they had been accused. People generally have not bought into the notion that someone would admit to crime of which they were innocent simply because that is not something they would ever do themselves (Gross \& Shaffer, 2012). However, false confessions are in fact, quite common (Bedau \& Radelet, 1987; Innocence Project, 2015; Scheck, Nuefeld, \& Dwyer, 2000). The Innocence Project (2015) suggests that the reason behind false confessions relates back to a belief that complying with police desires and confessing to committing the crime is more beneficial than maintaining their innocence.

Paradigm shift. According to Packer's two models, criminal procedure can either be based on Crime Control or Due Process. The Crime Control Model values the suppression of crime as the single most important task of the criminal justice system (Goldenstein, 1973). This model emphasizes the criminal justice system's ability to efficiently apprehend, try, and convict as many offenders as possible (Goldenstein, 1973). To accomplish this task, Findley (2008) suggests, "the system depends on quick resolution of questions of factual guilt by police through informal investigation processes and interrogations, with minimal review or oversight by formal adversarial adjudication," 
(p. 8). This model relies greatly on the screening process administered by law enforcement and prosecutors to ascertain guilt and hopefully lead to a resolution in the form of a guilty plea. Packer's other model, the Due Process Model, values individual rights as opposed to crime solving. In keeping with its core value of presumption of legal innocence there is no legitimacy to the case until it has been publicly heard and evaluated giving the accused an opportunity to refute the claims of their guilt.

In order to create a model that is best suited to embody what the innocence movement represents, there needs to be a shift to embrace a model combining both Crime Control and Due Process. There is the goal of ascertaining the truth, i.e., finding the true perpetrator, as well as ensuring that the rights of the defendant being considered. Although these rights are not always extensively exercised, they do provide evidence for a blurring of the two models (Findley, 2008). Both models are designed to solve crimes and distribute appropriate sanctions to the real offender. Findley (2008) found that police, prosecutors, judges, and victim advocates are all becoming involved in the reform efforts of defense attorneys to strengthen the reliability of the criminal justice system, specifically in convicting the guilty and protecting the innocent.

It is no surprise that Colvin (2009) argued strongly against the crime control model as it asserts the assumption that if a defendant has entered the adjudication stage, then they must be guilty. The focus of getting criminals off the street quickly takes precedence over finding the truth, which sets the stage for a number of potential negative consequences, including misconduct at the hands of law enforcement or prosecutors and even wrongful conviction. 


\section{Defining Wrongful Conviction in Past Research}

Much past research on wrongful convictions has focused on what causes wrongful convictions and perceptions of wrongful convictions from both the public and those involved in the criminal justice system (Gould \& Leo, 2010; Gross, Jacoby, Matheson, Montgomery, \& Patel, 2005; Huff, 2004; Huff, Rattner, \& Sagarin, 1986; Martin, 2002; Ramsey \& Frank, 2007). It is difficult to gain an accurate understanding of the true nature of wrongful convictions for a number of reasons. For example, there is no way to determine if a person has been wrongfully convicted, but their name has yet to be cleared through the exoneration process. Another difficulty when studying wrongful convictions lies in the basis of the wrongful conviction. It may be based on factual innocence or legal innocence. Forst (2004) described the differences as errors of due process and errors of impunity. Errors of due process can take the form of violations of defendants' rights of factually innocent defendants (Forst, 2004). Errors of impunity occur when the justice system fails to apprehend a perpetrator or acquits a factually guilty defendant (Forst, 2004).

Zalman, Smith, \& Kiger (2008) explain that wrongful convictions can also result from procedural errors which negate the fair trial aspect of the Constitution, leading to an acquittal. Acquittals based on legal innocence occur as a result of error during the criminal adjudicatory process, not because the defendant actually innocent of the crime in question. However, most researchers do not focus on wrongful conviction based on legal innocence, as there is a possibility that the defendant should have been convicted.

Past research on wrongful convictions has focused heavily on exonerations based on factual innocence. It is not enough for a convicted offender to claim innocence to 
draw a conclusion of wrongful conviction. Gross \& Shaffer (2012) explain exoneration based upon factual innocence as "a defendant who was convicted of a crime [and] was later relieved of all legal consequences of that conviction through a decision by a prosecutor, a governor or a court, after new evidence of his or her innocence was discovered, (p. 6). Essentially, the initial guilty verdict is overturned as a result of new evidence, which could show the initial defendant's innocence, the guilt of another suspect, or that a crime had never occurred. This sets a standard by which no one doubts the innocence of the defendant. This is the standard used by most researchers studying wrongful convictions (Colvin, 2009; Gould \& Leo, 2012; Zalman, Smith, \& Kiger, 2008).

A wrongful conviction can only lead to exoneration when there is sufficient evidence to persuade a governor, prosecutor, or a court that the convicted defendant is not actually guilty (Gross, 2008). The term exoneration is used to officially and legally declare a defendant not guilty of a crime of which they had been previously convicted. This may include the pardon of a governor, a court's dismissal of charges, and acquittal after re-trial (Gross et al., 2005). According to the National Registry of Exonerations, exoneration is a process by which a person who was convicted of a crime has either been declared factually innocent by a government agency that has the authority to make that assertion; or has been relieved of all the consequences of the criminal conviction by a government official who has the authority to take that action. The acquittal, dismissal, or pardon must come as a result of the evidence of innocence that was not initially presented. 


\section{Prevalence of Wrongful Conviction}

When an innocent person is wrongfully convicted, a number of people are harmed in the process. The true offender remains at large and free to victimize other individuals (Huff, 2002). Meanwhile, the innocent defendant must contend with the dangers associated with being imprisoned (Gould \& Leo, 2010). These potential dangers include both physical and psychological trauma. Physical traumas may include assaults, threats, sleep deprivation, and even fear for their lives (Grounds, 2004). Wrongfully convicted individuals may experience a variety of psychological traumas including psychiatric disorders such as post-traumatic stress disorder (PTSD), adjustment disorders, generalized anxiety disorder, and dysthymic disorder (Simon, 1993). The initial trauma occurs at the time of arrest and involves an acute psychological trauma, usually “involving experiences of overwhelming threat," (Grounds, 2004, p. 176). These feelings grow exponentially through chronic psychological trauma from "years of notoriety, fear, and isolation in their claims of innocence," (Grounds, 2004, p. 176). Individuals who are wrongfully imprisoned also must contend with losses in the form of separation from loved ones, missed opportunities, and personal life (Grounds, 2004).

Society's perceptions of and trust in the criminal justice system are also negatively impacted by wrongful convictions (Gould \& Leo, 2010). The legitimacy of the criminal justice system is challenged when the individuals are wrongfully convicted. This distrust in the effectiveness and integrity of the system creates a burden on individuals responsible for the operation of the criminal justice system (Ramsey \& Frank, 2007). This burden is unfortunate because it remains unlikely that any system, including our own, will have the capability to "apprehend, prosecute, and incarcerate every person, 
or even most people, guilty of serious crimes for which incarceration would be an appropriate sanction," (Findley, 2008, p. 5). Wrongful convictions have been described as "an injustice inflicted directly by the State itself, which undermines respect for and faith in our criminal justice institutions and the rule of law," (Findley, 2008, p. 5). Regardless of the numerous precautions taken, the only way to prevent the occurrence of wrongful conviction is to abstain from prosecuting anyone, which is a completely unrealistic alternative (Lillquist, 2005).

Researchers have attempted to ascertain the rate of recurrence of wrongful convictions. In their 1987 study, Bedau and Radelet studied death penalty cases in New York during an 85-year period (1900-1985). They discovered that during those 85 years, 350 wrongful convictions had occurred and 23 innocent prisoners had been wrongfully executed (Bedau \& Radelet, 1987). More recently, Gross et al., (2005) examined exoneration cases from 1989 to 2003, finding 340 instances of wrongful convictions. Similar to the Dotson case, DNA testing was used in 144 of those 340 cases. As of January 2015, the National Registry of Exonerations has identified a total of 1,728 exonerations of wrongfully convicted individuals.

Additionally, some researchers have delved into the perceptions of criminal justice professionals regarding the frequency of wrongful convictions. Ramsey and Frank (2007) did so by surveying criminal justice professionals in Ohio. Overall, survey participants categorized as criminal justice professionals believed wrongful convictions occurred only between .5 percent and one percent of the time (Ramsey \& Frank, 2007). However, defense attorneys believed wrongful convictions were more frequent, occurring at a frequency of one percent to three percent. Ramsey and Frank (2007) also hoped to 
establish perceptions of system errors that contributed to the frequency of wrongful convictions. The results of this portion of their study indicated that respondents perceived system errors to occur more than infrequently but less than moderately frequent (Ramsey \& Frank, 2007). The system errors referred to in their study were described as professional errors and misconduct.

As of January 7, 2015, the National Registry of Exonerations database contains information on a total of 1,728 exonerations. Official Misconduct (47 percent) is the second most frequent contributing factor, coming behind Perjury/False Accusation (55 percent). Oftentimes, most exoneration cases involve more than one contributing factor in the wrongful conviction. As such, for the purposes of this study, it is important to note the co-occurrence rates of other contributing factors with official misconduct: DNA (164, 9.5 percent), Mistaken Witness Identification (209, 12 percent), False Confession (145, 8 percent), False/Misleading Forensic Evidence (163, 9 percent), Inadequate Legal Defense (177, 10 percent), and Perjury/False Confession (626, 36 percent). These frequent cooccurrences provide support for the need to better understand each of these contributing factors.

Innocence projects. Innocence projects, are organizations that look deeper into claims of innocence and attempt to exonerate innocent people who have been convicted of a crime they did not commit. These organizations were created out of a sparked interest following the first DNA exoneration. In 1983, James C. McCloskey founded the first innocence project known as Centurion Ministries, INC (Krieger, 2011).

Barry Scheck and Peter Nuefeld founded the Innocence Project in 1992 at Cardozo Law School to assist prisoners who could be proven innocent through DNA 
testing (Innocence Project, 2015). Currently, The Innocence Project has a staff of more than fifty people, including six full time staff attorneys (Innocence Project, 2015). The Innocence Project also holds annual conferences to improve the state of legislation regarding DNA and other aspects of the criminal justice system through research, training, and scholarship. These conferences involve consultation with local, state, and federal law enforcement officials and legislators. Not only has The Innocence Project contributed to the creation of other innocence projects across the country, but they have also established resources available to the other innocence projects. For example, the Brief Bank is a resource with briefs about common issues faced in exoneration cases.

Innocence project organizations are important because it is unlikely that the government would actively seek out instances of their own wrongdoing. The founding of the first few organizations and public concern laid the foundation for the creation of more than sixty innocence projects today. These projects have been instrumental to the education of the public, to the freedom of innocent people, and to uncovering the numerous factors that contribute to wrongful convictions.

\section{Factors Causing Wrongful Conviction}

Thorough examinations of wrongful convictions have established a number of seemingly consistent factors related to instances of wrongful convictions (Bedau \& Radelet, 1987; Borchard, 1932; Gross et al., 2005; Huff et al., 1996; Ramsey \& Frank, 2007; Smith et al., 2011, etc.). The most common causes, according to the National Registry of Exonerations (2016) are mistaken witness identification, perjury or false accusation, false confession, false or misleading forensic evidence, and official misconduct. 
There are a number of factors that may contribute, to wrongful convictions. In 2009, Eric Colvin wrote an article entitled Convicting the Innocent: A Critique of Theories of Wrongful Conviction. Throughout this paper, Colvin addressed past consensus regarding causes of wrongful convictions and presented an alternative approach. Much of past research focused on the legal causes of error, while Colvin (2009) focused on two other types of errors that are described as causal factors. The first are errors that occur when wrongful accusations are initially made after investigations have occurred. These include errors by forensic scientists, law enforcement, or mistaken eyewitnesses (Colvin, 2009). The second type of error Colvin (2009) addresses includes those that occur in the adjudicative process that should have prevented wrongful convictions and correct previous instances of error. These errors include those made by attorneys or judges or as a result "from the deficiencies in the institutional framework for the conduct of trials," (Colvin, 2009, p. 174). The alternative approach focuses on an interaction between factors occurring at the investigative and adjudicative stages. Colvin (2009) explains that while "wrongful accusations do not necessarily lead to wrongful convictions. They lead to wrongful convictions when the safeguards to the criminal justice system fail," (p. 174).

Colvin (2009) believed that errors made during the investigative process should be corrected during the adjudicative stage. However, in instances of wrongful convictions, none of these errors are corrected. Therefore, Colvin (2009) believed it was highly unlike that a single factor was likely to cause a wrongful conviction. Colvin (2009) explains that there are a number of inherent safeguards in place to protect against the conviction of innocent defendants. Some of these protections include: 
rules respecting the admissibility of evidence; ethical obligations for prosecuting counsel; institutional arrangements for the accused to be legally represented; a requirement for jury unanimity or at least for a heavy majority verdict; and a requirement for guilt to be proved beyond reasonable doubt (Colvin, 2009, p. 181).

For a wrongful conviction to take place, all of these safeguards must fail in some fashion. This includes failure to utilize the safeguard properly at all or if it is only utilized in part. Therefore, Colvin (2009) found that all instance of wrongful conviction have more than one contributing error. One error occurs during the investigation process of the offence leading to a wrongful accusation. The National Registry of Exonerations would include mistaken witness identification, false accusation, false confession, or official misconduct by law enforcement, in this category. The other error occurs during the trial stage "when the various safeguards for the protection of innocent persons fail to correct the investigative error," (Colvin, 2009, p. 181). These include false or misleading forensic evidence, perjury, and instances of prosecutorial misconduct. It is important to also address the more specific contributing factors to wrongful conviction.

Official misconduct. Official misconduct takes on many forms depending on the individual involved in the misconduct. Most commonly, law enforcement and prosecutors are the most common participants. However, forensic analysts are another part of the criminal justice system in which official misconduct could potentially occur. There are instances where forensic analysts provide inaccurate statistics regarding scientific evidence. This could also be considered a form of forensic misconduct. The majority of forensic scientist analysts are ethical people. "They use the best scientific 
techniques available at the time to deliver objective, solid information - regardless of whether the science favors the defendant, supports the prosecution or is inconclusive," (Innocence Project, 2015). However, there are some instances in which the forensic scientist is inadequate and makes mistakes. These mistakes may be caused by insufficient resources, lack of time, poor support, or a lack of training. Regrettably, these mistakes are not the only instances of forensic misconduct. Some analysts knowingly engage in forensic misconduct and impact numerous cases. These instances of misconduct include fabricating test results, reporting certain results despite no actual test running, and concealing test results favorable to the defendant. The Innocence Project (2015) found that in virtually all of these scenarios, the analysts' misconduct led to several separate wrongful convictions, sometimes in various states.

In April 2015, a FBI representative gave formal acknowledgement that all 28 members of the FBI Laboratory's microscopic hair comparison unit gave flawed testimony in almost every trial in which they presented evidence against criminal defendants for a period spanning almost two decades prior to 2000 (Hsu, 2015). Ninetysix percent of the 500 cases that had been reviewed as of April 2015, dating back to 1972, included flawed testimony or reports from 26 FBI forensic examiners (Hsu, 2015). The FBI admitted that prior till 2012, hair examiners "lacked written standards defining scientifically appropriate and erroneous ways to explain results in court," (Hsu, 2015). Even as of April 2015, "there is no accepted research on how often hair from different people may appear the same," making it's use inadmissible in court (Hsu, 2015).

Prosecutorial misconduct. Members of law enforcement are not the only members of the criminal justice system to experience tunnel vision. Anyone involved in 
a criminal proceeding, including prosecutors, judges, defense attorneys, and investigators, can be impacted by tunnel vision. Prosecutors are under pressure to ensure the conviction of the suspect provided by the police. There is a heavy emphasis on prosecutors having high conviction rates. The societal focus on conviction sets the stage for ignoring errors made throughout various stages of criminal proceedings, or acceptance of them as simply a common consequence of the way the system works. In 2011, William Stuntz published a book entitled The Collapse of American Criminal Justice addressing how the unraveling of the criminal justice system happened and how best to repair our dysfunctional system. Stuntz (2011) emphasizes that the vast expansion of prosecutorial power as well as increase in number of criminal charges has led to prosecutors pressuring defendants into plea bargains without having to prove guilt. Given the power of the crime control model, and the vast desire to obtain convictions, it is reasonable to assume that prosecutors are viewing defendants with an assumption of guilt instead of innocence. As a result of the expansion of prosecutorial power without an accompanying set of counter-balances, the potential for abuse within the system vastly increases.

One of the contributing factors to the criminal justice system was the shift in focus regarding trials and acquittals (Stuntz, 2011). Prosecutors during the Gilded Age would initiate trials as soon as they met the legal burden of proof for a grand jury, probable cause, and would convict after proving the case beyond a reasonable doubt. Prosecutors today avoid pursuing a case unless the evidence, from the beginning, is 'clear and convincing.' Borchard (1932) explains that prosecutors' emphasis on conviction as victory is something that will help their reputation, and as such, their focus shifts from 
finding who is truly guilty to which cases and suspects are more likely to improve their statistics. In his book, Prosecution Complex: America's Race to Convict and Its Impact on the Innocent, Daniel Medwed (2012) argued that the two roles American prosecutors are asked to play, "advocate and servant of justice", have competing interests (p. 3). Medwed (2012) suggests that the competing interests appear in the form of being asked to convict criminals while also protecting the rights of defendants. Unfortunately the role of zealous advocate tends to take precedence, while defendants' rights are shunted aside (Medwed, 2012). There is an institutional complex created by professional incentives and psychological pressures in most prosecutorial offices that leads prosecutors to make garnering convictions their main focus (Medwed, 2012). Prosecutors' role as advocates of the government is measured based on their success rates in terms of convictions (Medwed, 2012). As a result of this particular measure of success, Medwed (2012) suggests that it is likely that sometimes prosecutors will suppress evidence, rely on imperfect statements, or contest requests for DNA testing in hopes of ascertaining a defendant's guilt and ensure a conviction.

The substantial emphasis on convictions may lead to misconduct which leads to wrongful convictions. Much of a prosecutor's decision to move forward with a case relies on evidence provided by the police. If the evidence given to a prosecutor is from an officer who has experienced tunnel vision in that particular case, the evidence may be incomplete and only focus on the suspect the officer believed to be guilty. If a police officer has shaped the evidence, by disregarding inconsistent evidence, to suggest that it must be the suspect he or she had in mind, that mindset is shifted to the prosecutor who will try the case (Findley \& Scott, 2006). It stands to reason that prosecutors who have 
pursued a case based on personal bias, limited information, or non-reliable evidence may be involved in contributing to a wrongful convictions (Ramsey \& Frank, 2007).

The definition of prosecutorial misconduct dates back to 1935 in the Supreme Court case Berger v. United States, in which Justice Sutherland defined it as "overstepp[ing] the bounds of that propriety and fairness which should characterize the conduct of such an officer in the prosecution of a criminal offense," (295 U.S. 78, 84). Also included in Sutherland's decision was a lengthy explanation of the various types of prosecutorial misconduct that may occur:

Misstating the facts in his cross-examination of witnesses; of putting into the mouths of such witnesses things which they had not said; of suggesting by his questions that statements had been made to him personally out of court, in respect of which no proof was offered; of pretending to understand that a witness had said something which he had not said and persistently cross-examining the witness upon that basis; of assuming prejudicial facts not in evidence; of bullying and arguing with witnesses; and in general, of conducting himself in a thoroughly indecorous and improper manner (295 U.S. 78, 84).

Justice Sutherland also included use of improper insinuations and assertions to mislead the jury as instances of prosecutorial misconduct. Since that time, several other Supreme Court cases have identified other examples of prosecutorial misconduct (Mooney v. Holohan 294 U.S. 103 (1935); Brady v. Maryland, 373 U.S. 83 (1963)).

It is the role of the prosecutor to ensure that law enforcement investigators, as well as government witnesses, are acting appropriately and testifying truthfully (Joy, 
2006). Therefore, prosecutors play an important role in oversight in both the law enforcement aspect (search procedure, obtaining confessions, eyewitness identifications) as well as the courtroom aspect (e.g., introduction of lab reports and the use of witnesses including jailhouse informants) (Joy, 2006).

Huff (2004) described five ways in which prosecutors may engage in misconduct. First, they may make inappropriate or provocative comments in the company of the jury. Prosecutors may mishandle physical evidence. This includes hiding, destroying, or tampering with evidence, including case files or court records. Another form of prosecutorial misconduct is through the use of false or misleading evidence. The use of false or misleading evidence is so frequent that it is often described as its own factor when discussing wrongful convictions. The next form of misconduct occurs when prosecutors threaten or badger witnesses. Finally, prosecutors may display an outright bias against the defendant and/or their counsel. Gould \& Leo (2010) also suggested that prosecutors may participate in coaching their witnesses to make their testimony more convincing, or may not even disclose pertinent evidence to the defense attorney.

Prosecutorial misconduct is one of the most frequently occurring factors that lead to wrongful convictions (Joy, 2006). In 2006, Peter Joy wrote an article entitled, “The Relationship Between Prosecutorial Misconduct and Wrongful Convictions: Shaping Remedies for a Broken System," which addressed the relationship between prosecutorial misconduct and wrongful convictions. Joy also defined the three main causes of prosecutorial misconduct and described how the combination of these factors could create a perfect setting for wrongful convictions. Peter Joy (2006) believed that prosecutorial misconduct occurred as a result of three institutional conditions: 
Vague ethics rules that provide ambiguous guidance to prosecutors; vast discretionary authority with little or no transparency; and inadequate remedies for prosecutorial misconduct, which create perverse incentives for prosecutors to engage in, rather than refrain from, prosecutorial misconduct (p. 400).

As a result of these three conditions, as well as undefined norms and a widespread lack of accountability for the ways prosecutors perceive and carry out their institutional and ethical obligations, it is not surprising that misconduct occurs so frequently (Joy, 2006).

Police misconduct. Law enforcement officials are also not exempt from instances of misconduct. Police are usually the first members of the criminal justice system to impact the case as they start the initial investigation that may eventually develop into a wrongful conviction case. Some forms of police misconduct take the form of previously described causes of wrongful conviction, such as false confessions. Huff (2004) suggests that some officers may engage in misconduct in other ways such as withholding evidence, obtaining false or coerced confessions, and using misleading line ups.

Findley and Scott (2006) use the idea of tunnel vision to explain some instances of police misconduct. Tunnel vision is defined as the human tendency to identify a single suspect and only accept evidence to help build a case for conviction and simply ignore, or even suppress evidence that may point towards that suspect's innocence (Findley \& Scott, 2006). This behavior is exhibited in officers who are so convinced of a suspect's guilt that they seek out testimony from unreliable witnesses or even coerce false confessions (Findley \& Scott, 2006). Rassin (2010) described instances of tunnel vision 
as ignoring indicators that the conclusion to which he or she had drawn is incorrect, as well as, stretching the interpretation of other evidence to support their conclusion.

It has been suggested that police misconduct in the form of tunnel vision tends to occur as a result of pressure from high profile cases (Martin, 2002). High profile cases place excess pressure on officers to solve the cases more quickly than usual, as they perpetuate fear of crime in the public and reduce confidence in the police. Huff, Rattner, and Sagarin (1996) explained the importance of the impact of pressure on police investigators from the media, public, lawyers, or even those within the department: This can lead interrogators to have a state of mind in which they are easily prone to believe in any suspect's guilt, even on the flimsiest of evidence. Once convinced of such guilt, they feel justified in resorting to any means, legal or illegal, from brutality to prevarication, from threats to promises that cannot be fulfilled, from trickery to dishonesty (including perjury), in order to prove in court what they already know, in their own minds, to be true - that the suspect committed the crime (p. 111).

The pressure to solve a high profile crime may cause the police to hone in on a single suspect, overlook contradictory evidence, and even obtain strong-armed confessions (McCloskey, 1989).

Oftentimes official misconduct occurs in conjunction with another factor that contributes to wrongful conviction. Ramsey and Frank (2007) believed that "system errors" (e.g. errors by defense attorneys, prosecutors, judges, and police) often precipitate, exacerbate, and amplify "non-system errors" (e.g. eyewitness and expert errors, false accusations and confessions, community pressure) (p. 444). The unethical 
behavior that is labeled misconduct usually leads to one of the more common factors associated with wrongful conviction such as false confession or fabricated evidence. Borchard (1932) believed that police or prosecution take part in some aspect of "fault, carelessness, or overzealousness" (p. 369).

Flawed science. The Innocence Project (2015) has found that unvalidated or improper forensics contributed to 47 percent of wrongful convictions. Although some forensic techniques have been scientifically validated, forensic analysts have been known to inaccurately convey the results during testimony during a trial (Innocence Project, 2015). As of February 1, 2009, more than half of the 225 wrongful convictions overturned by DNA testing involved improper forensic science in their initial convictions. However, according to the National Registry of Exonerations, as of January $7,2015,395$ of the total 1,707 exonerations (23 percent) listed false or misleading forensic evidence as a contributing factor.

Most instances of issues with forensic science evidence relate to methods and techniques that have not yet been scientifically validated. These techniques usually involve comparing impression marks or substances such as hair or fiber; most of which were created for the sole purpose of solving crimes. Many of these forensic testing methods have been applied in practice with little to no scientific validation or adequate assessment of reliability. As a result, these methods "lack scientifically acceptable standards for quality assurance and quality control before their implementation in cases," (Innocence Project, 2015, no page number). These missing scientific standards have impacted trials and thereby impacted the way forensic science evidence relates to wrongful convictions. 
Research has shown that sometimes the testimony of forensic analysts is improper in more than one way (Garret \& Neufeld, 2009). Forensic analysts have been known to testify about forensic techniques, that although have been practiced for many years, do not have the benefit of being supported by scientific research. However, these techniques have somehow come to be recognized and reiterated as fact regardless of scientific backup. For example, analysts have testified regarding "efforts to match a defendant's teeth to marks on a victim or attempts to compare a defendant's voice to a voicemail recording," (Innocence Project, 2015, no page number). These methods are not tested against the most basic scientific standards. Juries accept the testimony as fact when being told by a forensic expert despite not knowing that these methods are not scientifically supported. Occasionally, testimony will include words like "match" or "are consistent with" convincing a jury of the how meaningful the evidence is. However without scientific research on the validity and reliability of the particular forensic analysis method, it is impossible to determine how rare similarities may be, changing the true meaningfulness of the evidence.

Eyewitness misidentifications. If an individual were an eyewitness to a crime, be it theft, burglary, robbery, drive-by shooting, or rape, deliberate or accidental, he or she may be asked by the police to provide a description of the offender at some point in the future. Wells (1993), explains that there is clearly a problem with eyewitness identification based on the following observations, "eyewitnesses in psychology experiments can often make inaccurate statements about a previously witnessed event, their false statements appear to be sincere, and faulty eyewitness accounts have been implicated as the primary single cause of documented false convictions," (p. 554). The 
Innocence Project (2015) found eyewitness misidentification to be the greatest contributing factor to wrongful convictions. According to the National Registry of Exonerations 32 percent $(546 / 1,707)$ of exonerations included mistaken witness identification as a contributing factor.

Research to support the idea that eyewitness identification is flawed has been conducted for the last century. Hugo Munsterberg's 1907 book, On the Witness Stand, questioned the reliability of eyewitness identification. In 1932, Edwin Borchard published Convicting the Innocent. As a part of Borchard's research, he studied 65 cases of wrongful conviction and identified eyewitness misidentification to be the most common contributing factor to wrongful conviction cases. This area of research is important because "false identification can directly incriminate an innocent suspect," (Wells et al., 1998). The Innocence Project suggests that there are two main variables impacting eyewitness identification. The first type is known as estimator variables. These are the factors that cannot be controlled by the criminal justice system. Much of the research specifically related to eyewitness identification has identified best practices that reduce the risk for false identification of an innocent suspect by an eyewitness.

False confession. Another common factor in wrongful conviction cases is false confessions. A false confession has been defined as, "an admission to a criminal actusually accompanied by a narrative of how and why the crime occurred — that the confessor did not commit," (Kassin et al., 2010, p. 5). In 1987, Bedau \& Radelet conducted a study looking at 350 cases of wrongful conviction and found that false confessions were a part of the cause of a wrongful conviction in 49 of the cases (14 percent) (Bedau \& Radelet, 1987). As of November 30, 2015, The National Registry of 28 
Exonerations dataset showed 13 percent $(217 / 1,707)$ having false confession as a contributing factor. According to the Innocence Project 25 percent of those wrongfully convicted and released as a result of DNA testing were caused by false confession (Innocence Project, 2015). In 2000, Scheck, Neufeld \& Dwyer found that 15 out of the 62 cases studied included false confessions ( 24 percent). Confessions, whether accurate or false, can be a result of a wide variety of factors. The Innocence Project (2015) suggests that all of the reasons behind false confessions relate back to a belief that complying with police desires and confessing to committing the crime is more beneficial than maintaining their innocence.

Some of these factors known to contribute to false confessions during a police interrogation include coercion, diminished capacity, duress, fear of violence, ignorance of the law, intoxication, mental impairment, misunderstanding the situation, threat of a harsh sentence, or the actual infliction of harm. Drizzen \& Leo (2004) also described instances in which law enforcement will use more elaborate strategies to elicit a confession by implementing water or electric torture or simply increasing the temperature of the interrogation room. The Innocence Project (2015) explains how it is entirely legal for interrogators to use deception or trickery, such as claiming there is evidence implicating them or they will avoid the death penalty, in order to get suspects to confess. When children confess it is often considered unreliable as they can be easy to manipulate or may be unaware of the severity of the situation. Oftentimes people under interrogation believe that they will be allowed to leave if they simply admit their guilt. False confessions from individuals who are not considered mentally capable are not uncommon as they often wish to accommodate the wishes of authority figures. Another interesting 
factor in the false confessions of the mentally disabled is that law enforcement interrogators are not always specially trained in questioning these types of suspects. Almost all individuals, not only the mentally disabled, will give false confessions as a result of a lengthy and exhausting interrogation.

Kassin et al. (2010) explained that literature has suggested at least four ways to determine if a confession is false. The first instance occurs when it is later discovered that no crime was committed. The next way to determine if a confession is false is when additional evidence is uncovered that it was physically impossible for the individual who had confessed to have committed the crime. Another way in which a confession can be determined to be false is through the apprehension of the genuine perpetrator with no prior connection to the current defendant. This apprehension must be co-occurring with some type of evidence (ballistics, physical evidence, intimate knowledge of nonpublicized crime details) that links the perpetrator to the crime (Kassin et al., 2010). The final way to determine if a confession is false is through the use of scientific evidence that affirms the innocence of the confessor. This is where the importance of postconviction DNA testing is validated.

Inadequate legal defense. The Sixth Amendment of the U.S. Constitution established the right to assistance of counsel for persons accused of crimes. However, the underfunded state of the criminal justice system has led to overloaded and occasionally incompetent defense lawyers. The lack of funding has also had a significant impact on the investigative process. Both of these issues can contribute to inadequate legal defense, which sometimes plays a significant role in instances of wrongful convictions. 
Inadequate legal defense at the hands of the defense counsel can contribute to wrongful convictions. For example, it is the responsibility of the defense attorney to ensure that their clients are not on the receiving end of mistaken eyewitness identification, law enforcement's rush to judgment, and/or a prosecutor's decision to withhold evidence. Some of the factors that contribute to ineffective defense counsel representation include lack of motivation, a lack of quality control regulation, and a significant shortage in funding (Gould \& Leo, 2010). The growth of the use of plea bargains can be attributed, in part, to the instruction of defense attorneys, alongside prosecutors and judges. Plea bargains occur when a defendant agrees to plead guilty in order to avoid life in prison or the death penalty. All participants associated with the legal side of the criminal justice system attempt to reach a plea agreement in hopes to avoid what has been described as time-consuming motions (Findley \& Scott, 2006).

Oftentimes criminal defendants are represented by public defenders. Most public defender programs exist to provide representation to people charged with a crime who are unable to afford a private attorney. In the past, prior to receiving relatively decent compensation for the work, public defenders consisted of two types of attorneys: brand new practicing attorneys who needed the money and experience and those attorneys who were likely to take on extremely large caseloads and move through them as quickly as possible so as to maximize profits in each case (Mounts, 1982). Today, however, the majority of public defenders offices lack funding and also are struggling from a shortage of staff. The combination of being short staffed and underfunded has led to extremely large caseloads and consequently, a struggle to cope with a high client to attorney ratio (Mounts, 1982). Modernized defender programs, in order to combat the large numbers, 
will attempt to assign an attorney to a specific courtroom as opposed to specific individual cases. Unfortunately this does not allow for proper preparation prior to trial as well as difficulty in staying in contact with the defendants, all of which can lead to errors or even wrongful conviction.

However, not all instances of inadequate legal defense are a result of high caseloads or lack of funding. Sometimes it may just be misconduct on the part of the defense counsel. When a defense attorney, public or private, is representing a defendant who already has two strikes against him or her, they have been known to behave in a nonefficient manner (McCloskey, 1989). For example, attorney and client communication, when it occurs, happens and a hurried and dismissive fashion. There are also issues with superficial or even non-existent investigations when the defense counsel does not actively pressure the prosecutor. In these situations, physical evidence may go untested and no forensic experts are included. These are more frequent occurrences of this type of injustice, as McCloskey (1989) believed that extremely competent criminal defense attorneys were becoming an extinct population.

More recently, the Innocence Project (2015) has found that some of the defense attorneys in previously overturned conviction cases, were guilty of sleeping in court, failing to investigate alibis, call or consult with experts, or even show up for hearings. Some of these defense attorneys were even disbarred shortly after the completion of a death penalty case (Innocence Project, 2015).

\section{Present Study}

There are numerous factors that play a significant role regarding wrongful convictions. For example, Saks \& Koehler (2005) identified some of these factors as 
eyewitness errors (74 percent), forensic science (66 percent), police misconduct (44 percent), prosecutorial misconduct ( 40 percent), bad lawyering ( 28 percent), false confessions (19 percent), dishonest informants (17 percent), and false witness testimony (17 percent). The majority of past research has focused heavily on the causes, consequences, and public opinion regarding wrongful convictions. Official misconduct has been established as a significant factor in wrongful conviction cases. The present study seeks to understand the role official misconduct plays in wrongful conviction cases. Is this primarily a prosecutor problem, or is it a bad cop problem, flawed forensic testimony, or is it some combination? The goal is to identify the following: most common sources and motivations of official misconduct, what other contributing factors are associated with official misconduct, and any patterns associated with instances of official misconduct. These research questions will be explained in greater detail in the next section. 


\section{CHAPTER III \\ METHODOLOGY \\ Research Design}

\section{Research Questions}

A wide variety of causes have been cited as factors that contribute to instances of wrongful conviction. Generally speaking, however, most occurrences of wrongful conviction involve more than one contributing factor. Organizations, such as innocence projects, that focus on assisting those who have been wrongfully convicted were created, in part, to fuel the research behind understanding the causes of wrongful conviction and how to best prevent them from occurring in the future. In 2012, to create a universal documentation of exonerations, the University of Michigan Law School and the Center on Wrongful Convictions at Northwestern University School of Law created a website known as the National Registry of Exonerations. This website also provides a breakdown of the various factors that may contribute to wrongful conviction. While it is important to understand the causes of wrongful convictions, there are gaps regarding research on each of the specific contributing factors in exoneration cases as well as the total number of exonerations. This research uses the National Registry of Exonerations to examine a number of questions about wrongful convictions:

1. What other contributing factors to wrongful convictions are associated with official misconduct? 
2. What criminal justice officials are engaged in misconduct?

a. Does official misconduct co-occur between different criminal justice officials?

3. What is the nature of official misconduct? What types of acts constitute misconduct?

a. Do these actions co-occur?

It is also important to note that the criminal justice system is quite complex and interrelatedness throughout the system is not uncommon. Therefore, it is important to note how some of the contributing factors to wrongful conviction are likely to occur in conjunction with one another. Much of past research has focused on a single contributing factor, such as eyewitness misidentification, as opposed to the more complex idea that there is a culture in law enforcement that relies on poorly identified or handled evidence (Leo, 2005). This is not to suggest that researchers have ignored this collaborative idea, but it remains to be studied in greater depth, especially with regard to an issue as serious as official misconduct.

To understand the role official misconduct plays in wrongful conviction cases, we must first identify the sources of official misconduct. It is important to know, not only the perpetrators of official misconduct, but understand the motivation behind their decision-making. Schoenfeld (2005) attempted to conceptualize prosecutorial misconduct by breaking down the motivating factors for prosecutors who participate in official misconduct. It is reasonable to assume that attorneys would not be the only participants in the criminal justice system susceptible to opportunities for misconduct. Antonio Lamer (2006), a former Chief Justice of Canada, found that many of these 
instances of misconduct do not originate from a place of malice, but sometimes may develop into something more overtly negative. Developing an understanding of the motivating factors behind the decision of a member of the criminal justice system to partake in some form of official misconduct has the potential to benefit future policies to deter wrongful convictions.

Finally, to best understand the presence of official misconduct in wrongful conviction cases we must carefully examine each case in which official misconduct played a significant role. It is necessary to understand the actions that are considered misconduct prior to attempting to remedy them. Identifying major correlations (positive or negative) among the types of misconduct will provide a more complete understanding of official misconduct and wrongful convictions.

\section{Research Methods}

The present study examines the role official misconduct plays in wrongful convictions by using a mixed-method approach utilizing both quantitative and qualitative research. The quantitative analysis is composed bivariate and multivariate statistics of secondary analysis of data on wrongful conviction cases that were exonerated and published on the National Registry of Exonerations website. This study uses an existing dataset created by The National Registry of Exonerations (NRE). The Registry is an online database of 1,722 (as of January 7,2016) exonerations that have been identified since 1989. The registry includes both empirical data for each case, as well as a summary and narrative descriptions of the facts of each case. The qualitative aspect of this study is a content analysis of the summary description narratives of the 814 cases on the National Registry of Exonerations database involving official misconduct. 
Each case is given a page detailing case information, both in paragraph and bulleted form, including county and state in which the case occurred, most serious crime and any additional convictions, the year the crime was reported, the year the exoneree was convicted, as well as the year they were exonerated. The summary page also includes the sentence received, exoneree's race, sex, and age, any contributing factors that led to the wrongful conviction, and whether DNA evidence contributed to the exoneration.

Most of the information previously mentioned on each of the exoneree's detailed summary pages is also included on a basic spreadsheet. However, this spreadsheet also includes other "tags" that the National Registry of Exonerations has recognized as a common characteristic of wrongful convictions. These "tags" include items such as guilty pleas, posthumous exonerations, female exonerees, federal cases, shaken baby syndrome cases, occurrence during the child sex abuse hysteria, and if a co-defendant confessed. The author created a new database in SPSS merging information provided only on the individual detail page for each case with information provided in the detailed spreadsheet view. In order to run quantitative analyses related to the research questions, additional variables were created to better measure the true nature of each of these exoneration cases. These variables can be seen in Table 1. 


\section{Table 1}

Quantitative Analysis Variables

\begin{tabular}{|c|c|}
\hline Last & The last name of the exoneree \\
\hline First & The first name of the exoneree \\
\hline Age & $\begin{array}{l}\text { The age of the exoneree on the date the crime } \\
\text { occurred }\end{array}$ \\
\hline Black & Whether the exoneree was black \\
\hline Caucasian & Whether the exoneree was Caucasian \\
\hline Hispanic & Whether the exoneree was Hispanic \\
\hline OtherRace & $\begin{array}{l}\text { Whether the exoneree was another race (excluding } \\
\text { black, Caucasian, or Hispanic) }\end{array}$ \\
\hline State & The state in which the crime occurred \\
\hline Crime & $\begin{array}{l}\text { The most serious crime for which the exoneree was } \\
\text { convicted }\end{array}$ \\
\hline AdditionalConviction & $\begin{array}{l}\text { Any additional crimes for which the exoneree was } \\
\text { convicted }\end{array}$ \\
\hline Convicted & The year in which the exoneree was convicted \\
\hline Exonerated & The year in which the exoneree was exonerated \\
\hline YrsToExon & $\begin{array}{l}\text { The number of years from the exoneree's conviction } \\
\text { to their exoneration }\end{array}$ \\
\hline DNAfactor & $\begin{array}{l}\text { Whether DNA evidence was essential in leading to } \\
\text { the exoneration }\end{array}$ \\
\hline MistakenWitnessID & $\begin{array}{l}\text { Whether the eyewitness misidentification was a } \\
\text { contributing factor }\end{array}$ \\
\hline FalseConfession & Whether false confession was a contributing factor \\
\hline PerjuryorFalseAccusation & $\begin{array}{l}\text { Whether perjury or false accusation was a } \\
\text { contributing factor }\end{array}$ \\
\hline FalseorMisleadingForensicEvidence & $\begin{array}{l}\text { Whether false or misleading forensic evidence was } \\
\text { a contributing factor }\end{array}$ \\
\hline OfficialMisconduct & $\begin{array}{l}\text { Whether official misconduct was a contributing } \\
\text { factor }\end{array}$ \\
\hline InadequateLegalDefense & $\begin{array}{l}\text { Whether inadequate legal defense was a } \\
\text { contributing factor }\end{array}$ \\
\hline MostSeriousCrime & What the most serious crime was registered as \\
\hline
\end{tabular}

\section{Analysis}

A content analysis was conducted on each of the pages depicting the crime and the wrongfully convicted individual's time in the criminal justice process for the 814 cases involving official misconduct. These pages include the same basic information 
included in the National Registry of Exonerations spreadsheet, but also include more detailed explanations of what happened throughout the exoneree's journey. This extra detail provided insight into the nature of the contributing factors associated with the wrongful conviction. As shown in Table 1, the initial codes included basic themes identified by the National Registry of Exonerations; however, any emergent themes were also coded. While conducting the content analysis, each summary was read while simultaneously looking for items to code. The contents of Table 2 describe the initial list of variables that was considered. However, while taking notes on each case, any additional variables that were identified were included in the analysis.

To understand the role official misconduct plays in wrongful convictions, it is first necessary to gain an understanding of basic breakdown of all the instances of wrongful convictions. Therefore, basic frequencies and descriptives of the dataset were run, including age, race, and gender. Next, the frequency of Official Misconduct was run to see how common instances of official misconduct are in exoneration cases. Frequencies were also run to determine which of the other contributing factors were most common. 


\section{Table 2}

\section{Content Analysis Coding Scheme}

Police Misconduct

Police Coercing False Confession

Police Withhold Evidence

Police Give Misleading Line Ups/Eyewitness ID

\section{Dirty Cop Coverup}

Prosecutorial Misconduct

Prosecutor Mishandle/Withhold Physical Evidence

Prosecutor Use of False or Misleading Evidence

Prosecutor Threaten or Badger Witnesses

Other Participant Misconduct

Forensic Expert Misconduct

Investigator Misconduct

Jury Misconduct

Social Worker Misconduct

Inadequate Legal Counsel

Official Misconduct Necessary for WC

Other Factors Associated with WC
Police significantly abused their authority in a manner that contributed to the exoneree's conviction

Police used unorthodox and abusive methods to get the exoneree to falsely confess

Police do not provide certain pieces of physical or material evidence to prosecutors or defense attorneys

Police deliberately attempt to manipulate, persuade, or coerce the eyewitness into making an identification

The misconduct was a result of a dirty cop attempting to cover his/her own wrongdoing Prosecutors significantly abused their authority in a manner that contributed to the exoneree's conviction

Prosecutors conceal exculpatory evidence from the defendant and the court

Prosecutors knowingly allow experts to testify to false or misleading evidence or false witnesses to testify in court

Prosecutors threaten or badger witnesses into testifying in court

Other government officials significantly abused their authority or the judicial process in a manner that contributed to the exoneree's conviction Forensic analysts falsely testified at trial or withheld exculpatory results

Defense Attorney, or other investigators (not law enforcement) failed to adequately investigate the crime

Jurors commit misconduct

Social workers utilized leading interviewing techniques with witnesses or victims

The exoneree's lawyer at trial provided obviously and grossly inadequate representation

Was the official misconduct necessary for the wrongful conviction? (i.e., would the wrongful conviction still have occurred without the evidence obtained by misconduct?)

What other factors (besides official misconduct) were associated with each wrongful conviction case 
Colvin (2009) determined that it is highly unlikely that in cases of wrongful conviction there will only be one contributing factor. Therefore, multiple bivariate correlation analyses were run to determine how closely related each contributing factor was, as well as crime types, to the factor of official misconduct, at a statistically significant level. This test determined how each of the contributing factors was related to official misconduct. Correlations were also run with each type of crime (child sex abuse, sexual assault, homicide, robbery, other violent crime, and nonviolent crime) to determine whether official misconduct was more likely to appear in a certain type of case.

Finally, multiple bivariate correlation analysis was run to determine how closely related each sub-category of official misconduct was to the others. This will help determine the nature of what official misconduct really was. Notes were taken to ensure the qualitative aspect of the research.

\section{Limitations}

Despite being the most complete exoneration database, the National Registry of Exonerations database does have some limitations. There are instances of wrongful convictions that are not available in this sample as this database consists only of known instances of exonerations since 1989. It is also important that this database only includes cases that have been noticed by individuals involved with the National Registry of Exonerations, therefore there are many cases likely to be missing. Another limitation for this particular study is the way in which instances of official misconduct are coded within the National Registry's database. In their 2012 report, Gross \& Shaffer explained that, "Investigative procedures that generate false evidence may or may not involve 
misconduct as we use the term. For example, an interrogation that produces a false confession will only be classified as misconduct if it was severely abusive," (p. 66). Similarly, "the process of obtaining a false eyewitness identification may involve misconduct, but only if it includes a deliberate attempt to manipulate, persuade or coerce the eyewitness," (Gross \& Shaffer, 2012, p. 66). Consequently, the data provided by the National Registry of Exonerations only includes instances of official misconduct that was uncovered in litigation or by journalists, making the totals severely underestimated.

\section{Conclusion}

It is important to study this topic as wrongful convictions have a serious impact on the perceptions of the criminal justice system. The legitimacy of the criminal justice system is challenged when the individuals are wrongfully convicted. I believe the legitimacy of the criminal justice system is exponentially challenged when issues of official misconduct are called into question. Therefore, this research contributes to the growing body of knowledge regarding common causes of wrongful convictions and provides greater insight into the issue of official misconduct. This holds true, as no empirical research has been done to break down the true nature of official misconduct. As a result of understanding the true nature of cases involving official misconduct, there is potential to create better policies in the future aimed at deterring wrongful convictions. 


\section{CHAPTER IV}

\section{ANALYSIS AND RESULTS \\ Analysis and Results}

This study builds on existing literature by using a content analysis to explore the instances of official misconduct in wrongfully conviction cases. The registry of exoneration reports that 814 cases (47.3 percent) involved official misconduct, but does not say anything about the nature of that. Are these cases involving prosecutors? Misconduct by police? Misconduct by other criminal justice officials or participants? What was the nature of the misconduct that led to wrongful conviction? The content analysis answers this basic question: what does official misconduct look like?

\section{Research Question 1: Other Contributing Factors and Official Misconduct}

The research begins by identifying the role of official misconduct within the larger realm of wrongful conviction. Official misconduct is one of several factors that contribute to wrongful convictions as shown in Table 3. Official misconduct is the second most frequent factor, occurring in 814 cases (47.3 percent). Only perjury/false accusation appeared in more cases $(n=924,53.7$ percent $)$. DNA was a factor in 407 (21.3 percent), Mistaken Witness Identification was a factor in 556 (32.8 percent), False Confession was a factor in 217 (12.6 percent), Perjury/False Accusation was a factor in 924 (53.7 percent), False or Misleading Forensic Evidence was involved in 380 (22.1 percent), and Inadequate Legal Defense occurred in 355 (20.6 percent). 
Wrongful convictions occur in a wide variety of crimes. Homicide was the most serious crime in 727 cases (42.9 percent). Sexual assault was the most serious crime in 277 instances (16.3 percent); child sex abuse followed with 186 cases (11 percent); robbery was the most serious crime in 97 occasions (5.7 percent); other nonviolent felony was the most serious crime in 108 cases (6.4 percent); and other violent felony was the least frequent with 49 occurrences (2.9 percent).

Table 3

Descriptive Statistics-National Registry of Exonerations

\begin{tabular}{|c|c|c|}
\hline & $\mathrm{N}$ & $\%$ \\
\hline \multicolumn{3}{|l|}{ Demographics } \\
\hline \multicolumn{3}{|l|}{ Race } \\
\hline Black & 785 & 45.6 \\
\hline Caucasian & 664 & 38.6 \\
\hline Hispanic & 191 & 11.3 \\
\hline Other & 82 & 4.8 \\
\hline \multicolumn{3}{|l|}{ Age (Mean: 28.30, SD: 9.984) } \\
\hline \multicolumn{3}{|c|}{ Contributing Factors of Wrongful Convictions } \\
\hline Official Misconduct & 814 & 47.3 \\
\hline DNA & 407 & 24 \\
\hline Mistaken Witness Identification & 561 & 32.6 \\
\hline False Confession & 217 & 12.6 \\
\hline Perjury/False Accusation & 924 & 53.7 \\
\hline False or Misleading Forensic Evidence & 380 & 22.1 \\
\hline Inadequate Legal Defense & 355 & 20.6 \\
\hline \multicolumn{3}{|l|}{ Crime Types } \\
\hline Homicide & 727 & 42.9 \\
\hline Child Sex Abuse & 186 & 11.0 \\
\hline Sexual Assault & 277 & 16.3 \\
\hline Robbery & 97 & 5.7 \\
\hline Other Violent Felony & 49 & 2.9 \\
\hline Other Nonviolent Felony & 108 & 6.4 \\
\hline
\end{tabular}

The descriptive breakdown of cases leads to the question of if certain contributing factors are correlated together. To examine this, a chi-square analysis was conducted to determine the association between two categorical measures. Table 4 provides the 
breakdown of co-occurrences between each of the contributing factors. The most frequent co-occurrence was between official misconduct and perjury/false accusation $(\mathrm{n}=$ 608). The second most recurrent association was between official misconduct and eyewitness misidentification $(\mathrm{n}=216)$. False confession $(\mathrm{n}=140)$ and false/misleading forensic evidence $(n=159)$ co-occurred with official misconduct quite frequently.

Table 4

Co-Occurrences of Contributing Factors $(N=1,722)$

\begin{tabular}{lllllll}
\hline & 1 & 2 & 3 & 4 & 5 & 6 \\
\hline Official Misconduct (1) & $\mathbf{8 1 4}$ & & & & & \\
Eyewitness Misidentification (2) & 216 & $\mathbf{5 6 1}$ & & & & \\
Perjury/False Accusation (3) & 608 & 129 & $\mathbf{9 2 4}$ & & & \\
False/Misleading Forensic Evidence (4) & 159 & 110 & 173 & $\mathbf{3 8 0}$ & & \\
False Confession (5) & 140 & 29 & 119 & 44 & $\mathbf{2 1 7}$ & \\
Inadequate Legal Defense (6) & 148 & 102 & 188 & 74 & 43 & $\mathbf{3 5 5}$
\end{tabular}

Note: Values in bold indicate total occurrences per category

The chi-square phi value indicates the strength of the likelihood of two variables being significantly more or less likely to co-occur. As shown in Table 5, there were a number of statistically significant correlations. In terms of this research the most important correlation discovered were those relating to official misconduct. For example, there was a small, positive correlation between official misconduct and false/misleading forensic evidence $(\mathrm{r}=.058, \mathrm{p}<.05)$. Essentially, official misconduct and false or misleading forensic evidence are more likely to co-occur, but the correlation was weak. Additionally there was a moderate, positive correlation between official misconduct and perjury/false accusation $(\mathrm{r}=.399, \mathrm{p}<.001)$, meaning that they are more likely to co-occur with a moderately strong correlation. 
Table 5

Chi-Squared Phi Values of the Contributing Factors $(N=1,722)$

\begin{tabular}{lllllll}
\hline & 1 & 2 & 3 & 4 & 5 & 6 \\
\hline Official Misconduct (1) & 1 & & & & & \\
Eyewitness Misidentification (2) & $-.122^{* * *}$ & 1 & & & & \\
Perjury/False Accusation (3) & $.399^{* * *}$ & $-.427^{* * *}$ & 1 & & & \\
False/Misleading Forensic Evidence (4) & $.058^{*}$ & -.041 & $-.087^{* * *}$ & 1 & & \\
False Confession (5) & $.131^{* * *}$ & $.156^{* * *}$ & .009 & -.016 & 1 & \\
Inadequate Legal Defense (6) & $-.057^{*}$ & -.042 & -.007 & -.015 & -.008 & 1 \\
\hline ***. Correlation is significant at the 0.001 level. & & & & & & \\
*. Correlation is significant at the 0.05 level. & & & & & &
\end{tabular}

Chi-Square analysis were also run with each type of crime in order to determine whether official misconduct was more likely to appear in a certain type of crime. Variables in this category included homicide, child sexual abuse, sexual assault, robbery, other violent felony, and other nonviolent felony. None of the chi-square analyses for this category resulted in a relationship between type of crime and official misconduct. It appears that official misconduct is not at all significantly associated to specific crime types.

\section{Research Question 2: Official Misconduct Offenders}

While the registry reports that almost half of all exoneration cases (47.1 percent) included official misconduct as one of the factors leading to wrongful conviction, it tells nothing of the nature of what it looks like. The registry does not explain what types of officials are committing misconduct. The primary goal of this research was to uncover the answer to this question, and all 814 cases were content analyzed and coded to determine what type of official committed the misconduct, and what forms that misconduct took. 
Table 6 presents basic frequencies and descriptives including age and race. The average age of exonerees in cases involving official misconduct is 28.03 years old. The average length of time from conviction to exoneration in this dataset was 12.08 years. Of the exonerees included in this analysis 385 (47.3 percent) were black, 316 (38.8 percent) were Caucasian, 98 (12 percent) were Hispanic, and 14 (1.7 percent) were another race other than Black, Caucasian, or Hispanic.

Table 6

Descriptive Statistics of Official Misconduct Dataset

\begin{tabular}{|c|c|c|}
\hline & $\mathrm{N}$ & $\%$ \\
\hline \multicolumn{3}{|l|}{ Demographics } \\
\hline \multicolumn{3}{|l|}{ Gender } \\
\hline Male & 750 & 92.1 \\
\hline Female & 66 & 8.1 \\
\hline \multicolumn{3}{|l|}{ Race } \\
\hline Black & 385 & 47.3 \\
\hline Caucasian & 316 & 38.8 \\
\hline Hispanic & 98 & 12 \\
\hline Other & 14 & 1.7 \\
\hline \multicolumn{3}{|l|}{ Crime Type } \\
\hline Murder/Attempt/Accessory & 481 & 59.09 \\
\hline Child Sex Abuse & 81 & 9.95 \\
\hline Drug Possession or Sale & 37 & 4.55 \\
\hline Other Nonviolent Crime & 20 & 2.46 \\
\hline Property & 14 & 1.72 \\
\hline Sexual Assault & 74 & 9.09 \\
\hline Violent Crime & 85 & 10.44 \\
\hline White Collar/Corruption & 22 & 2.70 \\
\hline \multicolumn{3}{|l|}{ Age (Mean: 28.03, SD: 10.263) } \\
\hline Years to Exoneration (Mean: 12.08, SD: 8.789) & & \\
\hline
\end{tabular}

The most serious crime conviction of the exonerations analyzed were, 481 murder/attempt/accessory (59.09 percent), 81 child sex abuse (9.95 percent), 37 drug possession or sale (4.55 percent), 20 other nonviolent crime (2.46 percent), 14 property 
(1.72 percent), 74 sexual assault (9.09 percent), 85 (10.44 percent) violent crime (10.44 percent), and 22 white collar/corruption ( 2.70 percent). Although not statistically significant relationships, the rates of official misconduct were highest in homicide (64 percent) and child sexual abuse cases (39 percent).

One of the primary purposes of the content analysis was to determine the types of officials that were involved in official misconduct. Table 7 demonstrates that of the 814 exoneration cases, official misconduct involved prosecutors in 616 cases (75.7 percent), police in 527 cases (64.7 percent), judges in 556 cases ( 32.8 percent), and other criminal justice participants in 235 (28.9 percent). Other criminal justice participant misconduct generally took the form of forensic analysts or other experts giving false testimony at trial $(n=120,14.7$ percent $)$ or social workers $(n=29,3.6$ percent $)$ or investigators $(n=127$, 15.6 percent) who used some sort of improper interviewing techniques. Investigators also failed to do any concrete inspecting of the crime. Juror misconduct also occurred in 10 (1.2 percent) cases. 
Table 7

Frequencies of Official Misconduct Dataset

\begin{tabular}{|c|c|c|}
\hline & $\mathrm{N}$ & $\%$ \\
\hline \multicolumn{3}{|l|}{ OM Contributors } \\
\hline Prosecutors & 616 & 75.7 \\
\hline Police & 527 & 64.7 \\
\hline CJ Participant & 235 & 28.9 \\
\hline Judge & 54 & 6.6 \\
\hline \multicolumn{3}{|l|}{ Prosecutorial Misconduct } \\
\hline Mishandle/Withhold Evidence & 531 & 65.2 \\
\hline False/Misleading Evidence & 213 & 26.2 \\
\hline Threaten or Badger Witnesses & 66 & 8.1 \\
\hline \multicolumn{3}{|l|}{ Police Misconduct } \\
\hline Coerced False Confession & 196 & 24.1 \\
\hline Withhold Evidence & 314 & 38.6 \\
\hline Misleading Lineups/Eyewitness ID & 121 & 14.9 \\
\hline Abuse/Intimidating Interrogation & 156 & 156 \\
\hline Dirty Cop Cover Up & 29 & 3.6 \\
\hline \multicolumn{3}{|l|}{ Other CJ Official Misconduct } \\
\hline Forensic Expert & 120 & 14.7 \\
\hline Investigator & 127 & 15.6 \\
\hline Jury & 10 & 1.2 \\
\hline Social Worker & 29 & 3.6 \\
\hline
\end{tabular}

Table 8 shows how many of the official misconduct cases involved just one type of misconduct. Only 332 (40.79 percent) of the cases involved only one type of misconduct. Forty-three percent included two types of criminal justice officials, 112 (13.76 percent) included three types, and only 12 (1.47 percent) included all four potential offenders (police, prosecutor, judge, and other participant).

Table 8

Number of Official Misconduct Offenders $(N=814)$.

\begin{tabular}{lcc}
\hline & $\mathrm{N}$ & $\%$ \\
\hline 1 & 332 & 40.79 \\
2 & 358 & 43.98 \\
3 & 112 & 13.76 \\
4 & 12 & 1.47 \\
\hline
\end{tabular}


The next step was to ascertain which types of misconduct were most likely to cooccur. The descriptives shown in Table 9 tell us that official misconduct is most frequently shared between both police (65 percent) and prosecutors (75 percent). In essence, police and prosecutors are almost equal opportunity offenders when it comes to cases of official misconduct. Three out of every four cases are likely to involve a prosecutor, but six out of ten cases involve a police officer. In addition, more than half of cases involving prosecutorial misconduct also included police misconduct $(n=345)$.

Table 9

\section{Co-Occurrences of Official Misconduct Offenders $(N=814)$}

\begin{tabular}{lllll}
\hline & 1 & 2 & 3 & 4 \\
\hline Police Misconduct (1) & $\mathbf{5 2 7}$ & & & \\
Prosecutorial Misconduct (2) & 345 & $\mathbf{6 1 6}$ & & \\
CJ Participant Misconduct (3) & 133 & 185 & $\mathbf{2 3 3}$ & \\
Judge Misconduct (4) & 38 & 44 & 21 & $\mathbf{5 4}$ \\
\hline
\end{tabular}

Note: Values in bold indicate total occurrences per category

The chi-square phi value was used to determine whether the existence of one specific type of offending official would be more or less likely to co-occur with another. As presented in Table 10, there were a few statistically significant correlations between official misconduct contributors. Police misconduct had a small negative correlation with other criminal justice official misconduct $(r=-.102, \mathrm{p}<.01)$ and a weak negative correlation with prosecutorial misconduct $(\mathrm{r}=-.322, \mathrm{p}<.01)$. The implication of this result is that where there was evidence of police misconduct there was a smaller likelihood to be prosecutorial misconduct, as well as other criminal justice participant misconduct. The negative correlation between police and prosecutorial misconduct was quite surprising considering the higher number of cases where they co-occurred. After looking at the large number of co-occurrences, it is a surprising result, since police and 
prosecutors often work together as part of the same larger team, and thus, collusion might be a plausible hypothesis. Yet, at the same time the best explanation for a lack of statistical correlation among official misconduct participants is what while they occur with frequency, they are not planned, and do not represent a broader conspiracy within a local criminal justice system.

Table 10

Chi-Squared Phi Values of Official Misconduct Offenders $(N=814)$.

\begin{tabular}{lllll}
\hline & 1 & 2 & 3 & 4 \\
\hline Police Misconduct (1) & 1 & & & \\
Prosecutorial Misconduct (2) & $-.322^{* * *}$ & 1 & & \\
CJ Participant Misconduct (3) & $-.102^{* *}$ & .055 & 1 & \\
Judge Misconduct (4) & .031 & .036 & .061 & 1 \\
\hline
\end{tabular}

***. Correlation is significant at the 0.001 level.

**. Correlation is significant at the 0.01 level.

Although these results are informative, we can get a better sense of how official misconduct plays out by exploring some qualitative examples from the content analysis. In what follows, descriptions and excerpts of specific cases will be used to illustrate the nature of official misconduct relationships between actors in the criminal justice system.

Police and prosecutorial misconduct. Police and prosecutorial misconduct had a moderate negative correlation $(\mathrm{r}=-.322, \mathrm{p}<.01)$, meaning what where there was police misconduct, there was a smaller likelihood of prosecutorial misconduct also occurring. The case of Warith Habib-Abdal, previously known as Vincent H. Jenkins, provides a nice illustration of this. Habib-Abdal was a 43-year-old African American convicted of sexual assault in New York. Despite the fact that Abdal did not even remotely fit the description given by the victim, he was still the prime suspect. The victim also failed to 
identify Abdal until she saw a 4-year old picture of him, portraying a completely different image. At trial, the judge commented on the improper police identification procedure, but continued to allow Abdal to be identified in court. Prosecution also attempted to admit analysis regarding identification based on eyelash hair, which had no scientific foundation.

Another important case involving both police and prosecutorial misconduct was that of Cy Greene. Greene was a 19-year-old African American convicted of murder and robbery in New York. During the investigation police had all the individuals included in the lineup were sitting down, despite the identification and description being based on the offender being a tall individual. During the trial, both police and prosecutors withheld name changes in various reports, and prosecutors withheld a redacted transcript of witness-audiotaped interview omitting the comment about the offender being tall.

Finally, Anthony Ross was a 21-year-old African American convicted of murder in Illinois. During the investigation and the trial, prosecution withheld prison tapes contradicting witness testimony. The judge identified the missing tapes as the one thing the defense attorneys were lacking in successfully discrediting the witness. Police also admitted to abuse during the interrogation, as well as threatening witnesses and fabricating statements in this and other cases.

The nature of the relationship between police and prosecutorial misconduct, although not statistically significant, is one of great magnitude. It was the most frequent co-occurrence of misconduct offenders, despite the negative statistical association. Perhaps this is a result of prosecutors committing misconduct in attempts to conceal the misconduct of police officers. Eric Colvin (2009) would explain this relationship was 
necessary for wrongful conviction. The police misconduct occurred during the investigation process and lead to a wrongful accusation, while the prosecutorial misconduct occurs during the trial stage and "fails to correct the investigative error," (Colvin, 2009, p.181). The legitimacy of the criminal justice system is challenged and placed in jeopardy when individuals are wrongfully convicted, especially when it is a direct result of misconduct by two actors of that system.

Police and other criminal justice participant. Police misconduct also had a weak negative correlation with other criminal justice official misconduct $(r=-.102$, $\mathrm{p}<.01)$. Marcellius Bradford was a 17-year-old African American convicted of kidnapping in Illinois. Police coerced false confession from Bradford's co-defendant. This co-defendant's false confession was corroborated by false testimony of Chicago police crime lab analyst. The forensic analyst's notes showing that the blood types of the defendants did not match crime scene samples were never disclosed to the defense lawyers. In a similar instance, Brenda Kniffen, a 29-year-old Caucasian convicted of child sex abuse in California, was a victim of invalid forensic testimony and police misconduct. The invalid forensic testimony came in the suggestion that a wink response during interviews with the child was indicative of sodomy. Additionally, police and prosecutors pressured alleged victims to testify falsely against their parents.

Kathryn Dawn Wilson was a 22-year-old Caucasian woman convicted of child sex abuse in North Carolina. Police misconduct occurred in the form of biased interviews of alleged child victims by police and therapists who believed that a terrible conspiracy was taking place. There were also numerous instances of other criminal justice participants committing misconduct. Multiple members of the jury involved in 
this case participated in different forms of misconduct. One juror failed to disclose his own past child sex abuse victimization, while another brought a magazine article detailing the supposed traits of pedophiles to court. A third juror even drove to the closed day care center to look at the alleged crime scene. Moreover, the judge not only improperly allowed the parents of some of the children to testify and did not properly inspect the investigative files requested by the defense to determine if they should be disclosed. The prosecution also utilized improper cross-examination and "grossly improper" closing arguments during the trial (National Registry of Exonerations, 2016).

This relationship is one of great importance as it shows that there are other actors in the criminal justice system that are capable of committing misconduct. Although the misconduct can occur at the same time, as in the case where both police and social workers employ improper interviewing techniques, the misconduct can also co-occur in separate ways. For example, the jury misconduct and police misconduct in Kathryn Dawn Wilson's case were two mutually exclusive events. Understanding the different ways in which other criminal justice officials may commit misconduct may help determine ways to prevent its occurrence at all.

\section{Research Question 3: Nature of Official Misconduct}

One of the goals of this thesis was to identify in what specific settings is official misconduct most likely to play a role, and more specifically identify the most frequent offenders. This analysis included potential for four categories of official misconduct offenders: police, prosecutor, judge, or other criminal justice participant. Very few judges tend to be involved in official misconduct, at least in the practice of formal recognition of wrongdoing. The largest category of offenders is prosecutors $(n=616)$. 
However, prosecutorial misconduct co-occurs with police misconduct in almost half of the cases. The next step would be to determine the nature of what this misconduct looks like.

Multiple sub-categories were created to isolate and understand the different behaviors and actions that were considered misconduct. The analysis included three types of prosecutorial misconduct (mishandle/withhold evidence; use false/misleading evidence; threaten/badger witnesses), five types of police misconduct (coerced false confession; withhold evidence; misleading lineups/eyewitness id; abuse/intimidating interrogation; dirty cop cover up), and four types of other criminal justice participant misconduct (forensic expert, investigator, jury, or social worker). The frequencies of each of these sub-categories are shown in Table 11. 
Table 11

Frequencies of Official Misconduct Sub-Categories

$\mathrm{N}$

Prosecutorial Misconduct

Mishandle//Withhold Evidence

False/Misleading Evidence

Threaten or Badger Witnesses

Police Misconduct

Coerced False Confession

Withhold Evidence

Misleading Lineups/Eyewitness ID

Abuse/Intimidating Interrogation

Dirty Cop Cover Up

Other CJ Participant

Forensic Expert

Investigator

Jury

Social Worker
120

531

213

66

196

314

121

156

29

127

10

29
65.2

26.2

8.1

24.1

38.6

14.9

19.1

3.6

14.7

15.6

1.2

3.6

Table 12 provides insight into the frequencies of co-occurrences of the different sub-categories of misconduct. The descriptives in this table show us that the most frequent co-occurrence is between police and prosecutors mishandling or withholding evidence ( $n=207,25.4$ percent). Oftentimes prosecutor's withholding of evidence cooccurs with other forms of police misconduct as well. For example, there were 88 cases in which prosecutors withheld evidence and police had coerced a false confession. A related relationship was the 56 cases in which prosecutors used false or misleading evidence and police had coerced a false confession. It is not unreasonable to think that the false evidence used by prosecutors at trials was the coerced confession. Similarly, 
there were 54 cases in which prosecutors withheld evidence and police committed abuse or intimidating interrogation of the defendant. Perhaps the evidence being withheld was of the police abuse. Finally, police conducted misleading or improper line-ups or eyewitness identifications and prosecutors withheld evidence in 63 cases. Oftentimes the narratives included in the content analysis explained that the evidence withheld was about contradictory eyewitness testimony or improper identification procedures.

It is also important to note the frequency in which other criminal justice participant misconduct co-occurs with prosecutors mishandling or withholding evidence $(\mathrm{n}=151)$ and prosecutors using false or misleading evidence $(\mathrm{n}=112)$. Another significant co-occurrence is that of dirty cop cover-ups and police withholding evidence $(n=27)$. Police withheld evidence in 93 percent of cases involving a dirty cop cover up. Although not surprising that law enforcement would want to hide their wrongdoing, it is still a significant relationship to note. 
Table 12

Co-Occurrences of Official Misconduct Sub-Categories $(N=814)$

\begin{tabular}{|c|c|c|c|c|c|c|c|c|c|c|c|c|}
\hline & 1 & 2 & 3 & 4 & 5 & 6 & 7 & 8 & 9 & 10 & 11 & 12 \\
\hline \multicolumn{13}{|l|}{ Police Misconduct } \\
\hline $\begin{array}{l}\text { Police Coerce False Confession } \\
\text { (1) }\end{array}$ & 196 & & & & & & & & & & & \\
\hline $\begin{array}{l}\text { Police Abuse/Intimidating } \\
\text { Interrogation ( } 2 \text { ) }\end{array}$ & 94 & 156 & & & & & & & & & & \\
\hline $\begin{array}{l}\text { Police Conduct Misleading Line } \\
\text { Ups/Eyewitness ID (3) }\end{array}$ & 17 & 17 & 121 & & & & & & & & & \\
\hline Dirty Cop Cover Up (4) & 3 & 3 & 6 & 29 & & & & & & & & \\
\hline Police Withhold Evidence (5) & 67 & 57 & 67 & 27 & 314 & & & & & & & \\
\hline \multicolumn{13}{|l|}{$\underline{\text { Prosecutorial Misconduct }}$} \\
\hline $\begin{array}{l}\text { Prosecutor Mishandle/Withhold } \\
\text { Evidence (6) }\end{array}$ & 88 & 54 & 63 & 3 & 207 & 531 & & & & & & \\
\hline $\begin{array}{l}\text { Prosecutor Threatens or Badgers } \\
\text { Witnesses ( } 7 \text { ) }\end{array}$ & 18 & 5 & 9 & 0 & 19 & 37 & 66 & & & & & \\
\hline $\begin{array}{l}\text { Prosecutor Uses False or } \\
\text { Misleading Evidence }(8)\end{array}$ & 56 & 34 & 25 & 0 & 55 & 149 & 17 & 213 & & & & \\
\hline \multicolumn{13}{|l|}{ Other CJ Participants } \\
\hline Forensic Expert (9) & 30 & 11 & 15 & 1 & 32 & 86 & 10 & 86 & 119 & & & \\
\hline Investigator (10) & 23 & 23 & 14 & 1 & 39 & 85 & 5 & 34 & 22 & 126 & & \\
\hline Jury (11) & 0 & 0 & 1 & 0 & 1 & 7 & 1 & 4 & 0 & 3 & 10 & \\
\hline Social Worker (12) & 4 & 11 & 4 & 0 & 1 & 14 & 0 & 9 & 1 & 26 & 0 & 29 \\
\hline
\end{tabular}

Note: Values in bold indicate total occurrences per category 
Additionally, chi-square phi value was run in order to determine how closely related each type of official misconduct was to every other type of official misconduct in this analysis. These results can be seen in Table 13. It is interesting to note some of these relationships. Police coercion of false confessions had a slight negative correlation with misleading line ups/eyewitness identification $(\mathrm{r}=-.098, \mathrm{p}<.01)$, a weak negative correlation with prosecutors mishandling/withholding evidence $(\mathrm{r}=-.240, \mathrm{p}<.01)$, and a weak positive correlation with police abuse/intimidating interrogation $(r=.412, \mathrm{p}<.01)$. It is not surprising that it is more likely that if police have coerced false confessions, there is also a higher likelihood that police abuse/intimidating interrogation has also occurred.

Another noteworthy moderately significant positive correlation was that of dirty cop cover up and police withhold evidence $(\mathrm{r}=.144, \mathrm{p}<.01)$. This means that where there was evidence of a dirty cop cover up there was a higher likelihood of police also withholding evidence. An additional unsurprising statistically significant correlation was between other criminal justice participant misconduct and prosecutors using false or misleading evidence $(\mathrm{r}=.316, \mathrm{p}<.01)$. This is not surprising as many of the contributors considered to be "other criminal justice participants" would be analysts and experts, who had falsely testified at trial. Other criminal justice participants who committed misconduct also had a weak negative correlation with police who withhold evidence $(\mathrm{r}=$ $-.144, \mathrm{p}<.01)$. 
Table 13

Chi-Squared Phi Values of Official Misconduct Sub-Categories $(N=814)$

\begin{tabular}{|c|c|c|c|c|c|c|c|c|c|c|c|c|}
\hline & 1 & 2 & 3 & 4 & 5 & 6 & 7 & 8 & 9 & 10 & 11 & 12 \\
\hline \multicolumn{13}{|l|}{ Police Misconduct } \\
\hline $\begin{array}{l}\text { Police Coerce False } \\
\text { Confession (1) }\end{array}$ & 1 & & & & & & & & & & & \\
\hline $\begin{array}{l}\text { Police Abuse/Intimidating } \\
\text { Interrogation ( } 2 \text { ) }\end{array}$ & $.412^{* * *}$ & 1 & & & & & & & & & & \\
\hline $\begin{array}{l}\text { Police Conduct Misleading } \\
\text { Line Ups/Eyewitness ID } \\
\text { (3) }\end{array}$ & $-.098^{* *}$ & -.054 & 1 & & & & & & & & & \\
\hline Dirty Cop Cover Up (4) & -.062 & -.043 & .031 & 1 & & & & & & & & \\
\hline $\begin{array}{l}\text { Police Withhold Evidence } \\
\text { (5) }\end{array}$ & -.051 & -.020 & $.144^{* *}$ & $.215^{* * *}$ & 1 & & & & & & & \\
\hline \multicolumn{13}{|l|}{$\underline{\text { Prosecutorial Misconduct }}$} \\
\hline Prosecutor & & & & & & & & & & & & \\
\hline $\begin{array}{l}\text { Mishandle/Withhold } \\
\text { Evidence (6) }\end{array}$ & $-.240^{* * *}$ & $-.313^{* * *}$ & $-.116^{* * *}$ & $-.222^{* * *}$ & .011 & 1 & & & & & & \\
\hline $\begin{array}{l}\text { Prosecutor Threatens or } \\
\text { Badgers Witnesses ( } 7 \text { ) }\end{array}$ & .022 & $-.087^{*}$ & -.010 & -.057 & -.060 & -.057 & 1 & & & & & \\
\hline $\begin{array}{l}\text { Prosecutor Uses False or } \\
\text { Misleading Evidence }(8)\end{array}$ & .031 & -.048 & -.052 & $-.114^{* * *}$ & $-.156^{* * *}$ & .059 & -.003 & 1 & & & & \\
\hline \multicolumn{13}{|l|}{ Other CJ Participants } \\
\hline Forensic Expert (9) & .009 & $-.106^{* *}$ & -.028 & -.061 & $-.102^{*}$ & .056 & .003 & $.430^{* * *}$ & 1 & & & \\
\hline Investigator (10) & -.058 & -.010 & -.045 & -.064 & -.067 & $-.082^{*}$ & -.065 & .008 & .031 & 1 & & \\
\hline Jury (11) & $-.063^{* *}$ & -.054 & -.015 & -.021 & -.065 & -.015 & .008 & .035 & -.046 & .045 & 1 & \\
\hline Social Worker (12) & -.046 & $.092^{* *}$ & -.006 & -.037 & $-.139^{* * *}$ & $-.123^{* * *}$ & -.057 & .021 & -.061 & $.394^{* * *}$ & -.021 & 1 \\
\hline
\end{tabular}

***. Correlation is significant at the 0.001 level.

**. Correlation is significant at the 0.01 level.

*. Correlation is significant at the 0.05 level. 
Again, understanding the lack of statistical significance in conjunction with such large co-occurrences is difficult. By exploring some qualitative examples from the content analysis will provide a much more complete portrayal of what these specific types of misconduct look like. These descriptions will also show what the co-occurrence of these actions may look like as well.

Police and prosecutors withhold evidence. Although it is not a statistically significant correlation, prosecutors mishandled or withheld physical evidence in 207 cases where police also withheld evidence. Ricardo Aldape Guerra was a 20-year-old Hispanic man convicted of murder in Texas. During the investigation, police officers who were searching homes for the suspects, forced residents to lie face-down outside and pointed guns at their heads, and many were rounded up and detained at the police station until the following morning. Multiple people witnessed the shooting, and overwhelmingly, they identified Carrasco Flores as the shooter. The police, however, willfully recorded inaccurate information or refused to include information that would exculpate Aldape Guerra. Witnesses, many of whom were not proficient in English, were threatened with legal action if they failed to sign the statements prepared by police. During a lineup, police walked the handcuffed Aldape Guerra past witnesses before asking them to identify the perpetrator. Witnesses were permitted to discuss their opinions and even encourage each other to select Aldape Guerra - and several did. The withheld evidence in this case involves inaccurately recorded information by three witnesses who specifically did not identify Aldape Guerra as the murderer. Additionally, prosecutor withheld information about the tests of trace metal from the murder weapon. 
Ulysses Rodriguez Charles was a 30-year-old African American man from Massachusetts convicted of Sexual Assault and Robbery. During the investigation, police ignored the hospital request for DNA swabs and in doing so, destroyed key evidence. Also the prosecutors in his cases elicited and presented false testimony from forensic analysts.

Jennifer Wilcox and Robert Aldridge were both convicted in Ohio of child sexual abuse. A neighbor reported to police that several neighborhood children, ages ranging from four to seven years old, had been engaging in sexual activities with each other. The parents of the children were allegedly involved in getting the children to engage in sex with each other. It was suspected that Robert Aldridge was the leader of the group of adults who repeatedly molested the children. The police misconduct involved in this case came as a result of intense interviewing and threatening and actually holding the siblings in order to coerce them to testify falsely against Aldridge and Wilcox. Of even greater importance were the exculpatory statements from the alleged victims that had been sanitized from police reports by the prosecution prior to giving the information to the defense.

Withholding evidence, by both police and prosecutors, is an extremely frequent occurrence. As previously mentioned, any form of misconduct is likely to have a detrimental impact to the legitimacy of the criminal justice system. By identifying that both of these actors are likely to withhold aspects of evidence during cases provides the opportunity for policy recommendations aimed at deterring this type of misconduct. Perhaps both of these actors are so focused on closing the case and obtaining a conviction, they will hide any evidence that is contradictory to what they say happened. 
Although not all instances of withheld evidence are done maliciously, the effects are the same, making this an issue that needs to be addressed.

Dirty cop cover up co-occurrences. There were 27 cases in which police withholding evidence co-occurred with a dirty cop cover-up $(r=.215, \mathrm{p}<.001)$. Seneca and Tari Adams were victims of a dirty cop cover up in conjunction with withheld evidence when dirty officers in Illinois brought them up on assault charges. After their convictions, it was discovered that the officers who had testified against Seneca and Tari were "indicted by a federal grand jury for planting evidence on defendants, falsely accusing defendants of having guns, and breaking into homes and robbing residents of guns, money and drugs and then filing false reports" to cover their tracks (National Registry of Exonerations, 2015). Similarly, Jamar Smythe, a 30-year-old African American man, was convicted of drug possession or sale and a traffic offense in New York based on multiple instances of police misconduct. The officer involved in the case falsified warrants, stopped Smythe based on information from a confidential informant, not on a traffic violation. Furthermore, a video surveillance tape documenting the location where the arrests and searches took place was withheld from the defense by law enforcement.

A final example of this combination of police misconduct can be seen in the case of Edward Williams. Williams was a 25-year-old African American man from Ohio who was convicted of assault. The investigating officer on this case dragged Williams to the pavement, where he was pepper-sprayed, punched and hit repeatedly with a police baton. During the trial, police lied about the abuse and concealed evidence proving his 
innocence in the form of video and audio recordings of the arrest. Eventually the truth was discovered on the recordings showing that Williams had been falsely arrested.

Additionally police conducted misleading lineups/eyewitness identifications in 6 cases in which there was also a dirty cop cover-up $(r=-.222, \mathrm{p}<.001)$. Although this statistic says that a dirty cop cover up and police conducting misleading lineups or eyewitness identifications are less likely to co-occur, the instances in which it does are quite interesting. Anthony Adams, Jesse Alvarez, Jorge Alvarez, and Luis Davalos were four of five defendants who were convicted of murder as a result of a dirty cop cover up in which police conducted improper and misleading eyewitness line ups and identifications. Two members of the Los Angeles Police CRASH unit, Rafael Perez and Sammy Martin, identified 18-year old Sonya Flores was a witness who was "close enough to the victim that her clothes were spattered with blood" (National Registry of Exonerations, 2015). Nearly five years following the shooting, Sonya Flores came forward and admitted to making the false identification because she had been dating Perez for two years. Perez asked Flores to select five defendants from a police book of gang members to take the fall for the shooting and murder he and other dirty cops had set up and committed.

There are major implications of the relationships between dirty cops covering their misconduct and police withholding evidence and prosecutors mishandling or withholding evidence. The relationship in which police withhold evidence can easily be explained as police withholding evidence of their own wrongdoing to ensure they do not get caught. In addition, prosecutors may be so focused on obtaining a conviction that 
they disregard the misconduct of police during the investigation and use whatever evidence they have been given, regardless of its accuracy.

Other criminal justice participant misconduct co-occurrences. The two most frequent co-occurrences with other criminal justice participant misconduct are prosecutor mishandle/withhold evidence (151 cases, $\mathrm{r}=-.006, \mathrm{p}<.01)$ and prosecutor uses false/misleading evidence (112 cases, $\left.\mathrm{r}=.316^{* * *}, \mathrm{p}<.001\right)$.

A prime example of a case involving a prosecutor who mishandled or withheld evidence and another criminal justice participant committing misconduct was in the case of Michelle Murphy. Not only did police coerce a false confession and falsely testify at trial, but the crime lab analyst on the case also falsely testified at trial. Prosecution also withheld the true results of forensic blood analysis. Similarly in Larry Randal Padgett's case both forensic analysts and prosecutors withheld results confirming the defense's finding that the blood tested the first time was not Padgett's. Another excellent example of this particular combination of misconduct occurred in the case of Ronnie Baylor, a 25year-old African American man convicted of sexual assault, robbery, burglary/unlawful entry, theft, and illegal use of a weapon. After being on the receiving end of multiple threats from law enforcement, Baylor falsely confessed. A lab report excluded Baylor from the crimes based on blood-type analysis. However, Baylor's lawyer did not subpoena the criminalist until the case came to trial, at which point he was on vacation and unavailable to testify. As a result, the lab report, which the analyst, prosecution, and defense knew about, was never admitted into evidence.

One of the 112 cases involving an alternative criminal justice participant misconduct and a prosecutor who used false or misleading evidence was the case of 
Dennis Halstead. A 26-year-old Caucasian man, Dennis Halstead was convicted of murder and rape in New York. During the investigation and the trial, the prosecution withheld knowledge of an intact vaginal swab that had never been tested. Additionally, hair evidence that had been presented at trial was commingled with others from the van. However it was never determined whether this commingling came as a result from negligence or misconduct (National Registry of Exonerations, 2015). Another important case was Joseph Awe's conviction of arson. The arson experts who testified at trial, who had been hired by an insurance company, used disapproved methodology to determine the cause of the fire. Furthermore, prosecutors did not reveal to the defense that the insurance company had paid the arson experts' fees, making their testimony potentially biased.

However, the relationship between other criminal justice participant misconduct and prosecutors using false or misleading evidence is incredibly important. Oftentimes this takes the form of experts and forensic analysts giving false testimony at trial or in reports, which prosecutors use in their arguments, ultimately leading to a wrongful conviction based on improper evidence. Based on the significance level of this relationship $\left(\mathrm{r}=.316^{* * *}, \mathrm{p}<.001\right)$, these two factors are far more likely to co-occur, making this a relationship that needs to be examined in greater detail. These two criminal justice actors are working together and committing misconduct, and in doing so are creating legitimacy issues for the criminal justice system.

Coerced false confessions and intimidating interrogation. Finally, it was not surprising that police coercion of false confessions and police abuse/intimidating interrogation co-occurred in 94 cases. Michael Hobley was a 26-year-old African 
American was convicted of murder and arson in Illinois. During his interrogation he was beaten, kicked, and suffocated by police. His alleged confessions were never documented, but were testified to by the police. Similarly, 32-year-old, Leroy Orange, an African American man convicted of murder, robbery, and arson in Illinois, signed a confession after 13 hours of interrogation by Caucasian police officers. It was later discovered that these officers had engaged in torture of various African American suspects throughout the years.

Michael Pardue, a 17-year-old Caucasian convicted of murder and robbery in Alabama, was interrogated, with few breaks, over the course of days by police. During the course of the interrogation he was severely beaten. Pardue asked for help and to have an attorney present on multiple occasions, but attorneys were stopped from gaining access to him. Pardue was not read his Miranda rights until the end of the interrogation, which not only involved physical beatings, but also threats of the death penalty. Likewise, David Bates, an 18-year-old African American, was convicted of murder, robbery, and assault in Illinois. Throughout the course of his interrogation he was punched repeatedly by officers and was nearly suffocated on four separate occasions. Bates confessed after fearing he would be killed. Several years later, it was discovered that Lieutenant Burge and his detectives tortured more than 100 African American men, including Aaron Patterson, Leroy Orange, Stanley Howard, and Madison Hobley, all of whom were included in this analysis.

This relationship is not a surprising one as police are using these intimidating interrogation tactics and abusing the defendants in order to obtain these false confessions. The presence of such a significant relationship between these two factors provides 
evidence for better policy and techniques regarding interviews and obtaining confessions. The standalone issue of police abuse is obviously one of greater importance, but its presence in conjunction with the successful gaining of false confessions is promoting it to an entirely different level, with serious consequences for the defendant beyond a onetime beating. 


\section{CHAPTER V \\ DISCUSSION}

\section{Discussion}

This research used the existing database of exonerations, the National Registry of Exonerations (NRE), to examine three research questions focusing on official misconduct. The detailed information regarding the nature of official misconduct that has contributed to wrongful convictions identified by this research could be beneficial in helping prevent future instances of official misconduct and wrongful convictions. The National Registry Exonerations defines official misconduct as "police, prosecutors, or other government officials significantly abused their authority or the judicial process in a manner that contributed to the exoneree's conviction." However, the registry does not indicate the nature of the official misconduct and if it was a result of prosecutors, police, and/or other criminal justice officials? This research aimed to uncover the nature of official misconduct through a qualitative examination of all wrongful conviction cases that include official misconduct. More specifically, it focused on attempting to answer the following questions: (1) what other contributing factors to wrongful conviction are associated with official misconduct? (2) What criminal justice officials are engaged in misconduct? And (3) what is the nature of official misconduct? What types of acts constitute misconduct?

The best way in which to provide a complete understanding of official misconduct and best answer these questions in their entirety was a mixed methods analysis utilizing 
both quantitative and qualitative research. As discussed in Chapter III, the quantitative analysis was comprised of basic descriptives and frequencies and bivariate analysis of a variety of variables in hopes of understanding the role of official misconduct in wrongful convictions. The qualitative aspect of this analysis came from a content analysis of the summary description narratives of 814 cases on the National Registry of Exonerations database involving official misconduct. The results provided a far more detailed picture of the nature of official misconduct and those who perpetrate this crime.

The study of the sources of official misconduct revealed who in the criminal justice system was making the mistakes or committing the misconduct. By identifying who is responsible for the instances of misconduct, researchers are able to recommend steps to prevent future instances of misconduct, and in doing so, also prevent wrongful convictions. Similarly, identifying the nature of what the misconduct actually looks like in terms of actions is extremely beneficial for researchers and policymakers.

Additionally, it was necessary to identify which of the remaining five factors that have previously been recognized in prior research as those most often associated with wrongful convictions and were most likely to co-occur with official misconduct. These five categories include eyewitness misidentification, false confessions, perjury/false accusation, false/misleading forensic evidence, and inadequate legal defense.

As a result of the breadth of this research, a variety of methods were chosen to provide the most comprehensive insight into the nature of official misconduct. Descriptives and frequencies were necessary to determine how often certain types of misconduct occurred and who the offender was. Bivariate analysis was used to gain understanding into which contributing factors, misconduct offenders, and types of 
misconduct might typically occur together. The bivariate analysis also provided insight into potential for future research and preventative measures for official misconduct. The qualitative aspect of this research was used in order to provide a more comprehensive and detailed look into what each of these types of misconduct looks in the real world.

As little research has been done on an in-depth analysis of the nature of official misconduct, the result of these findings are particularly important. This research has shown that official misconduct occurs in 814 , or nearly 48 percent of cases. This is similar to what past research has found about official misconduct being a significant contributing factor to wrongful convictions. Understanding more about the nature of official misconduct (i.e., the actors involved and the actions that constitute misconduct) is extremely important as criminal justice system officials have been tasked with a duty to find the truth and deliver justice. The public entrusts them to do this. However, with an alarmingly high rate of misconduct among those criminal justice system actors, the trust of the public and the credibility of the system as a whole may be lost. Criminal justice agencies need to examine their policies and behaviors to determine the likelihood of detecting and stopping misconduct.

The results of this analysis provided in-depth insight into the nature of official misconduct in relation to wrongful convictions. In regards to police misconduct, the most frequent co-occurrence was found between police who coerced false confessions and used abuse or an intimidating interrogation tactics to do so $(\mathrm{n}=94)$. This relationship is extremely important because they are significantly more likely to occur together $(\mathrm{r}=.412, \mathrm{p}<.001)$. It is plausible that the abuse and intimidating interrogation tactics are done to garner a confession, and as evidenced by this research, it is a technique 
that works quite frequently. In order to prevent this, there should be more oversight into police investigation procedures. This should include not only the interview process, but also witness identification procedures and evidence logging. This research revealed there were far too many instances of police covering up their own wrongdoing by withholding evidence not only from the defense, but even the prosecutors on the case $(n=27, r=$ $.215, \mathrm{p}<.001)$. In order to deter officers, the creation of consequences and/or punishments for such wrong doing would be a step in the right direction.

Official misconduct was positively correlated with only one other type of contributing factor, false/misleading forensic evidence $(\mathrm{r}=.071, \mathrm{p}<.01)$. The presence of this statistically significant relationship provides further proof for the presence of misconduct in actors involved in creating and utilizing false forensic evidence. These actors may be police, prosecutors, or forensic analysts. This concept is plausible as the results showed a strong positive relationship between prosecutor using false or misleading evidence and forensic expert misconduct $(r=.430, \mathrm{p}<.001)$. This was the strongest relationship found in the entire analysis that occurred in 86 cases. This type of official misconduct can be viewed as the result of tunnel-vision towards obtaining a conviction.

Findley and Scott (2006) defined tunnel vision as the human tendency to identify a single suspect and only accept evidence to help build a case for conviction and simply ignore, or even suppress evidence that may point towards that suspect's innocence. Although this definition is concentrated more on police misconduct, tunnel-vision is still applicable to prosecutors. For instance, if law enforcement has shaped the evidence, by disregarding inconsistent evidence, to suggest that it must be a certain suspect, that 
mindset can and will be shifted to the prosecutor who will try the case (Findley \& Scott, 2006). Prosecutors must also contend with the societal focus on garnering high conviction rates. The emphasis on conviction sets the stage for paying no attention to errors made throughout various stages of criminal proceedings, or acceptance of them as simply a common consequence of the way the system works. This also applies to the utilization of false testimony and fabricated evidence aimed at obtaining a conviction. Rassin (2010) described this relationship best as ignoring indicators that the conclusion to which an individual had drawn is incorrect, as well as, stretching the interpretation of other evidence to support their conclusion.

\section{Conclusions and Implications}

In order to incorporate checks on the vast amount of power of prosecutors and law enforcement officials, criminal justice reform commissions need to be established to study these issues and advocate for the necessary changes. The most influential and beneficial commission would be comprised of members of the public, crime victims, and experts from within the criminal justice system. The wide variety of perspectives involved provides the opportunity to foster a new system that is not plagued by injustice. According to the Innocence Project (2015), criminal justice reform commissions have already been formed with the goal of understanding the causes of wrongful convictions and creating reforms to prevent these types of injustices. For example, the Oklahoma Bar Association established the Oklahoma Justice Commission in September of 2010. Through research focused on the common causes of wrongful convictions, including forensic science misconduct and government misconduct, the aim of the Commission is to "create remedial strategies designed to reduce or lessen the possibility of conviction of 
the innocent," (Innocence Project, 2015). The Commission hopes to providing training of criminal justice practitioners, develop proper procedures and create procedural and educational remedies. Many District Attorney's offices are creating Conviction Integrity Units (CIUs) to re-examine past convictions that have been questionable in nature. However, many of these units are quite new and all operate according to their own set of internal guidelines instead of a universal guideline. The Innocence Project has developed a set of guidelines that they believe to be the best practice to assist these types of units in effectively inspect past miscarriages of justice.

\section{Future Research}

Future research should focus on more in-depth qualitative studies each type of sub-category of misconduct to better understand its role within wrongful convictions. For example, perhaps interviews with police, prosecutors, and other criminal justice system participants that have been identified as common offenders of misconduct about their actions. It would also be beneficial to understand what that various criminal justice reform commissions are proposing in terms of policy and legislation around the country to prevent wrongful convictions. Similar to this line of thinking, there should be program evaluation of criminal justice reform commissions to ensure the effectiveness of their existence.

\section{Contributions}

This research has provided a contribution to past literature in the form of insight into nature of official misconduct, for the National Registry of Exonerations database, in a manner that is far more detailed. Past research on official misconduct has generally provided vague information about what actions constitute misconduct and focused more 
on the perceptions of its presence and potential justifications for the misconduct. Additionally, past research on the topic of official misconduct has rarely viewed the topic as a whole, instead focusing on one offender (i.e., police or prosecutors) at a time.

Similar to Huff (2004), this research identified the various behaviors by prosecutors that constituted misconduct. However, this research differs in that it also identified misconduct by other criminal justice participants, including forensic experts, investigators, juries, social workers, judges, and law enforcement. In addition, this research identified the likelihood of different criminal justice actors' misconduct occurring together. Overall, this research provided a more complete understanding of the nature of official misconduct, in terms of offenders and actions, and the role it plays in wrongful convictions. 


\section{REFERENCES}

Bedau, H. A., \& Radelet, M. L. (1987). Miscarriages of justice in potentially capital cases. Stanford Law Review, 21-179.

Berger v. United States, 295 U.S. 78, 84 (1935)

Borchard, E. M., \& Lutz, E. R. (1932). Convicting the Innocent: Sixty-five Actual Errors of Criminal Justice. Garden City Publishing Company.

Brady v. Maryland, 373 U.S. 83, 87-88 (1963)

Clayton, M. (1995). Captives of flawed justice systems. Christian Science Monitor, 87(83), 9.

Colvin, E. (2009, June). Convicting the innocent: A critique of theories of wrongful convictions. In Criminal law forum (Vol. 20, No. 2, pp. 173-192). Springer Netherlands.

Ferguson-Gilbert, C. (2001). It Is Not Whether You Win or Lose, It Is How You Play the Game: Is the Win-Loss Scorekeeping Mentality Doing Justice for Prosecutors. Cal. WL Rev., 38, 283.

Findley, K. A. (2008). Toward a New Paradigm of Criminal Justice: How the Innocence Movement Mergers Crime Control and Due Process. Tex. Tech L. Rev., 41, 133.

Forst, B. (2004). Errors of justice: Nature, sources and remedies. Cambridge University Press. 
Goldstein, A. S. (1973). Reflections on Two Models: Inquisitorial Themes in American Criminal Procedure. Stan. L. Rev., 26, 1009.

Gould, J. B., \& Leo, R. A. (2010). One hundred years later: Wrongful convictions after a century of research. Journal of Criminal Law and Criminology, 100(3).

Gross, S. R., \& Shaffer, M. (2012). Exonerations in the United States, 1989-2012. U of Michigan Public Law Working Paper, (277).

Gross, S., Jacoby, K., Matheson, D., Montgomery , N., \& Patil, S. (2005). Exonerations in the united states 1989 through 2003. The Journal of Criminal Law \& Criminology, 95, 523-560.

Gross, S. R. (2008). Convicting the innocent. The annual review of law and social sciences, 4, 173-192.

Grounds, A. (2004). Psychological consequences of wrongful conviction and imprisonment. Canadian Journal of Criminology and Criminal Justice, 46(2), 165-182.

Harris, D. A. (2012). Failed evidence: Why law enforcement resists science. NYU Press.

Hsu, S. (2015, April 18). FBI admits flaws in hair analysis over decades. Retrieved December 10, 2015, from https://www.washingtonpost.com/local/crime/fbioverstated-forensic-hair-matches-in-nearly-all-criminal-trials-fordecades/2015/04/18/39c8d8c6-e515-11e4-b510-962fcfabc310_story.html

Huff, C. R. (2002). Wrongful conviction and public policy: The American society of criminology 2001 presidential address. Criminology, 40(1), 1-18. 
Huff, C. R. (2004). Wrongful convictions the american experience. Canadian Journal of Criminology and Criminal Justice, 46(2), 107-120.

Huff, R.C., Rattner, A., \& Sagarin, E. (1996). Convicted, but innocent: Wrongful conviction and public policy. Thousand Oaks, California: SAGE Publications.

Innocence Project. (2015). The Causes of Wrongful Conviction. Retrieved April 14, 2015, from http://www.innocenceproject.org/causes-wrongful-conviction

Joy, P. A. (2006). The relationship between prosecutorial misconduct and wrongful convictions: Shaping remedies for a broken system. Wisconsin Law Review, 2006, 399.

Kassin, S. M., Drizin, S. A., Grisso, T., Gudjonsson, G. H., Leo, R. A., \& Redlich, A. D. (2010). Police-induced confessions: Risk factors and recommendations. Law and human behavior, 34(1), 3-38.

Krieger, S. (2011). Why our justice system convicts innocent people, and the challenges faced by innocence projects trying to exonerate them. New Criminal Law Review, $14,333$.

Lamer, A. (2006). The Lamer Commission of Inquiry Pertaining to the Cases of: Ronald Dalton, Gregory Parsons, Randy Druken. St John's: Office of the Queen's Printer.

Leo, R. A. (2005). Rethinking the study of miscarriages of justice: Developing a criminology of wrongful conviction. Journal of Contemporary Criminal Justice, 21(3), 201-223. 
Leo, R. A., \& Gould, J. B. (2009). Studying wrongful convictions: Learning from social science. Ohio State Journal of Criminal Law, 7, 2010-11.

Lillquist, E. (2005). Absolute Certainty and the Death Penalty. Am. Crim. L. Rev., 42, 45.

Lucas, J. W., Graif, C., \& Lovaglia, M. J. (2006). Misconduct in the prosecution of severe crimes: Theory and experimental test. Social psychology quarterly, 69(1), 97-107.

Martin, D. L. (2002). Lessons about justice from the laboratory of wrongful convictions: Tunnel vision, the construction of guilt and informer evidence. University of Missouri-Kansas City School of Law UMKC Law Review, 70, 847-864.

McCloskey, J. (1989). Convicting the innocent. Criminal Justice Ethics, 8(1), 54-59.

Meares, T. L. (1995). Rewards for good behavior: influencing prosecutorial discretion and conduct with financial incentives. Fordham L. Rev., 64, 851.

Medwed, D. S. (2012). Prosecution complex: America's race to convict and It impact on the innocent. NYU Press.

Mooney v. Holohan, 294 U.S. 103, 112-13 (1935)

National Registry of Exonerations, The. (2016). UPDATE:2015. Retrieved from: http://www.law.umich.edu/special/exoneration/Documents/Exonerations_in_2015 .pdf

Phillips Jr, W. E. (2012). Organizational change and prosecutorial misconduct. Journal of Global Intelligence \& Policy, 5(6). 
Raeder, M. (2007). See No Evil: Wrongful Convictions and the Prosecutorial Ethics of Offering Testimony by Jailhouse Informants and Dishonest Experts. Fordham Law Review, 76.

Ramsey, R. J., \& Frank, J. (2007). Wrongful Conviction Perceptions of Criminal Justice Professionals Regarding the Frequency of Wrongful Conviction and the Extent of System Errors. Crime \& Delinquency, 53(3), 436-470.

Rassin, E. (2010). Blindness to alternative scenarios in evidence evaluation. Journal of Investigative Psychology and Offender Profiling, 7, 153-163.

Scheck, B., Neufeld, P., \& Dwyer, J. (2001). Actual innocence (pp. 163-203). New York: Signet.

Schoenfeld, H. (2005). Violated trust: Conceptualizing prosecutorial misconduct. Journal of Contemporary Criminal Justice, 21(3), 250-271.

Smith, B.P. (2005). The history of wrongful convictions. Hastings Law Journal, 56, 1185.

University of the Michigan Law School and the Center on Wrongful Convictions at Northwestern University School of Law. (2015). The National Registry of Exonerations [Data file]. Retrieved from http://www.law.umich.edu/special/exoneration/Pages/detaillist.aspx

Zalman, M., Smith, B., \& Kiger, A. (2008). Officials' estimates of the incidence of “actual innocence” convictions. Justice Quarterly, 25(1), 72-100.

Doi:10.1080/07418820801954563 


\section{APPENDIX}

\section{SAMPLE NARRATIVE OF CONTENT ANALYSIS}

\section{Wayne Dill, Jr.}

From 1984 through 1986 at least 30 defendants were convicted of child sex abuse and related charges and sentenced to long prison terms in a series of inter-related cases in Kern County, California, and an additional 8 defendants accepted plea bargains that kept them out of prison. Over time, 20 of the defendants who were sentenced to prison were exonerated, the earliest in 1991 and the latest in 2008. In most of these exonerations the children who had testified that they had been abused recanted their testimony. In all of the exonerations there was evidence that the complaining witnesses - some as young as four years old - had been coerced or persuaded by the authorities make false accusations.

The Kern County cases are the oldest and largest of several groups of prosecutions that occurred in a wave of child sex abuse hysteria that swept through the country in the 1980s and early 1990s. Some (but not all) of these cases included allegations of satanic rituals. Many focused on day care centers. Nationally, there have been dozens of exonerations in child sex abuse hysteria cases.

Most of the Kern County child sex abuse cases were multi-defendant group prosecutions. Grace Dill was one of the "Pitts Seven", a group of six family members and one family friend who were accused of participating in a "child sex abuse ring" in Kern County in the mid-1980s. 
Sexual abuse allegations first arose in January 1984, after Grace Dill's six-yearold grandson, Brian, and other children were caught playing in a sexually-inappropriate manner at school. When questioned by a school counselor, Brian made remarks suggesting that his mother, Marcella Pitts, had sexually abused him. The counselor filed a report with Child Protective Services (CPS) and officials began interviewing Brian and his older brothers, aged eight and ten.

Over the next several months, the boys were repeatedly questioned by the police. In the interviews, the boys provided increasingly extreme accusations of abuse, eventually alleging that they had been abused by various family members and indicating that their step-sisters and cousins had also been abused. Based on the testimony of the Pitts boys, police also interviewed other children in the family, some of whom at first denied ever being abused and later began to report abuse, and some of whom consistently denied being abused.

Ultimately, the accusations extended to include Marcella Pitts's husband, Rick Pitts, her siblings Colleen Dill Forsythe and Wayne Dill, Jr., their mother, Grace Dill, and Colleen Forsythe's husband Wayne Forsythe. Family members were accused of abusing their children, nieces, nephews, and grandchildren. Gina Miller, a family friend, was also accused of abuse, though only two of the children were able to identify her in a line-up.

Rick and Marcella Pitts and Colleen Dill Forsythe were arrested on June 4, 1984. On July 25,1984 , all three were charged with conspiracy, forcible lewd and lascivious acts on children under the age of fourteen, use of children for purposes of pornography, child endangerment, and assault. Over the course of the next month, Gina Miller, Grace 
Dill, Wayne Dill Jr. and Wayne Forsythe were also arrested and charged with similar crimes.

The cases were consolidated in late 1984, and the "Pitts Seven" trial began December 13, 1984. Eight children testified, two of whom denied that any abuse had occurred. The prosecution presented evidence that one of the children tested positive for the bacteria gardnerella vaginalis, and a medical expert falsely claimed that this organism was found only in sexually active individuals. One prosecutor compared the defendants' alleged acts to atrocities committed during the Holocaust and referred to Christ as a witness to children's credibility. There was no physical evidence to support the children's allegations of abuse.

On August 2, 1985, all seven defendants were convicted of a total of 377 counts of child sex abuse and conspiracy. Wayne Forsythe was sentenced to 285 years in prison. Rick and Marcella Pitts and Colleen Dill Forsythe each received 373 years in prison. Grace Dill, Wayne Dill Jr. and Gina Miller each received terms of 405 years in prison. All seven defendants appealed their convictions, alleging that prosecutorial misconduct had prevented them from receiving a fair trial. In 1989, two of the children recanted their testimony. In 1990, all of the convictions were reversed by the California Court of Appeal, based on findings of egregious prosecutorial misconduct. The judge found that prosecutors had made numerous inappropriate comments which were likely to have prejudiced the jury against the defendants, and during the investigation, had knowingly coerced child witnesses into making false accusations; for example, one child was told that if she testified as instructed, she would be able to go home, but if not, she would never see her mother again. 
The misconduct was so egregious that the Court of Appeal directed the trial court to enter an order dismissing specified counts. The remaining counts were dismissed in 1991; by 1994, all the child witnesses had recanted and claimed their testimony was coerced.

\section{Word Count: 830}

